\title{
La tipología del utillaje lítico del yacimiento de La Pila (Cuchía, Mogro, Cantabria)
}

\author{
manuel Ángel laguera Garcia
}

\section{CONSIDERACIONES INICIALES}

En este trabajo que, aunque sólo abarca el estudio tipológico del utillaje lítico del yacimiento cántabro de La Pila, se inscribe en uno de sentido más amplio que pretende analizar los aspectos técnicos y los modelos de fabricación de la industria lítica de dicho yacimiento, se han utilizado dos listas-tipo, la tradicional de Sonneville-Bordes/Perrot (19541956) y la denominada de «Burdeos».

La lista de "Burdeos" se diseñó en un intento de cubrir las lagunas que se constatan al ver que la lista-tipo de "Sonneville-Bordes/Perrot" responde más adecuadamente a los periodos antiguos del Paleolítico Superior que a los del Magdaleniense, el Aziliense y sus contemporáneos europeos. La asunción de ésta ha sido rápida en algunos ámbitos lo que ha llevado a publicar yacimientos exclusivamente con esta lista-tipo como es el caso del yacimiento de Duruthy (Arambourou, 1978).

Se ha desistido de utilizar las listas analiticas de Laplace, fundamentalmente por la falta de estudios amplios que permitieran una comparación con este yacimiento. Todo esto nos lleva a plantearnos el sentido de las listas tipológicas.

No vamos a entrar a fondo en la cuestión metodológica, en el sentido de "procedimiento", ni en la cuestión teórica en el sentido de "estruc- 
tura formal del discurso cientifico" (Vicent, 1981), es decir, en la validez o invalidez de las listas-tipo al uso, pero sí vamos a realizar las siguientes consideraciones sobre las principales criticas que se han realizado a las listas-tipo.

La primera crítica básica que se puede hacer es que las listas-tipo tienen su origen en una consideración de la Prehistoria de carácter clásico de tipo positivista y evolutivo, en algunos casos también cíclico (léase por ejemplo La degeneración aziliense), y con conceptos heredados de la Geologia al primar la estratigrafía comparada. Esta base teorica solamente ha sido tamizada, sin modificación alguna, por la utilización de criterios estadísticos, tanto simples (gráficas acumulativas e indices) como complejos (cálculos de distancia, análisis factoriales... ). Estos últimos han sido utilizados sin una discusión previa sobre la adecuación o no del modelo estadístico con los fines e intenciones de los estudios prehistoricos.

Otra crítica es la falta de homogeneidad de los criterios utilizados para definir los tipos. Se utilizan criterios "morfológicos" (ej.: hojita truncada), criterios "funcionales" (ej.: raspador, buril...), "tecnológicos" (ej.: buril transversal sobre truncadura lateral) y «tipométricos» (ej.: microgravette).

Una tercera es complementaria de la anterior. Junto a la variedad de los criterios de caracterización del tipo se encuentra la indefinición de muchos de ellos (ej.: punta aziliense), así como la gran carga de subjetividad que conllevan términos como "atípico", "truncadura oblicua", etc.

Esto ha sido señalado muy adecuadamente por Laplace (1976 y anteriores) así como por los autores que le han seguido. Se define la lista-tipo de S-B/P como de carácter empírico, que exige un "aprendizaje" previo para una buena utilización, a lo que se une además el que lleve consigo la diversidad de criterios por parte de los autores, lo que puede conferir o recrear "personalidad" propia a los yacimientos según quien sea el que clasifique.

Por último, una cuarta critica que se suele utilizar es el de la inadecuada equiparación de los conjuntos definidos a partir de la aplicación estadística de las lista-tipo a "culturas", en el sentido de grupos humanos estabilizados e incluso en un sentido "étnico", y sobre la falsedad de la valoración cronológica de los cambios tipológicos. El prototipo de esta última crítica se encuentra en las consideraciones de Binford (1973), seguidas en España sobre todo por Strauss (1983). 
Sin cerrar en absoluto el tema. nos parecen éstas las criticas fundamentales que se han podido realizar a las listas-tipo tradicionales, a las que realizamos las acotaciones siguientes.

Empezando por la última, el desarrollo de las técnicas de radiocarbono ha permitido señalar que existe una variación cronológica de los conjuntos definidos tipológicamente, obviando parcialmente la argumentación circular de las listas-tipo '. A esto se une que los intentos de desarrollar una "tipología funcional» propugnada por Binford (1973) parecen que se han abortado. Por otro lado, parece que los estudios de huella de uso (Pincevent, Meer, Verberie) están demostrando que los útiles retocados están más utilizados que los que no están retocados y que, al menos algunos tipos, tienen una correspondencia entre la hipotética "función” de la lista-tipo y la utilización real (Oliva, 1984).

En el caso de la cornisa cantábrica es Strauss (1983) el que mantiene, utilizando incluso dataciones, la invalidez de la periodización y la tipología clásica por estar encuadradas en un mismo ámbito cronológico similares. Esto ha sido rebatido, entre otros, por González Sainz (1989) para el Magdaleniense Medio y Superior y Aziliense al situarlos en "horquillas" temporales consecutivas, que sólo se solapan en los extremos.

Por otro lado, son escasos los que mantienen la significación cétnica» de las divisiones tipológicas, uno de estos pocos es Garcia Guinea (1985). La equiparación del término "cultura material» con el de "cultura social" va siendo abandonada, o al menos eludida, por los investigadores actuales.

En cambio, se está imponiendo el concepto cultura en sentido restringido, como complemento de la significación económica de los conjuntos materiales.

En este sentido el concepto "Cultura" se utiliza en íntima comunicación con otros como "modelo" de fabricación o "tradición" con un sentido que está próximo al de "aprendizaje» del artesano. Algunos autores, utilizando criterios sociológicos y semióticos en la línea de Hodder de 1982, están revitalizando el valor de la tipología de lista-tipo o intuitiva, como la de mayor posibilidad de aprehender el "modelo" de útil desarrollado por las comunidades prehistóricas. Esto ha revitalizado el criterio de "fósil-guía", que, según opinión que compartimos, no dejó de ser utiliza-

Uno de los casos mas claros es el que. según su definicion, "punta aziliense" es prácticamente toda punta que aparece en el Aziliense y. a su vez, un nivel es aziliense porque. entre otros elementos. presenta puntas azilienses. 
do después de plantearse la tipología "estadistica» (Oliva, 1984, y Djindian, 1984).

Las criticas por la de falta de criterios homogéneos, la indefinición y la carga de subjetividad son, desde nuestro punto de vista y en líneas generales, inobjetables. Pero, por otra parte, creeemos que una buena parte de las criticas son ineludibles al estudiar la industria lítica. La tipología analítica desarrollada por Laplace (1976 y anteriores) también presenta una importante carga de subjetividad. La clasificación y/o distinción de los tipos (analíticos) a partir de la morfología del retoque («simple», "plano", "abrupto»...) exige también un periodo de aprendizaje y los criterios del clasificador son determinantes en los casos dudosos, bastante comunes por cierto.

Además consideramos que, a| menos, los tipos más complicados. como el buril "busqué", reponden adecuadamente a un modelo mental de útil del artesano prehistórico; y que, en cambio, la reducción del útil a la morfología del retoque puede implicar la clasificación en tipos diferentes a útiles que responden al mismo criterio; por ejemplo, el reavivado de un raspador puede suponer la clasificación de este útil como un abrupto frente a otro raspador no reavivado. Este mismo peligro existe en las tipologías "intuitivas" pero evidentemente es más reducido.

Por último, no hay nada que objetar a la crítica al fundamento teórico (positivismo, mera descripción...) siempre que genere una nueva respuesta metodológica coherente. Es evidente que estudios sólo tipológicos tienen escasa significación más allá de sus aspectos de cronología relativa y de comparación con conjuntos líticos más o menos contemporáneos.

E desarrollo de técnicas y/o de estudios renovadores en el campo de la industria lítica, las huellas de uso, la cadena técnica, los estudios de distribución de restos y de materia prima, ha permitido entrar en niveles "descriptivos" mas amplios. Lo que a su vez ha posibilitado aproximaciones a los aspectos económicos en sentido amplio, y alguna que otra derivación en cuestiones sociales de los comportamientos humanos en la Prehistoria. Pero estas nuevas técnicas sólo significan una reforma de los antiguos aspectos metodológicos, manteniéndose el mismo fundamento teórico.

\section{SITUACIÓN Y ESTRATIGRAFIA}

La cueva de La Pila se encuentra cerca de la playa de Marzán y a 700 metros de la ribera derecha del estuario de San Martín de la Arena 
de la desembocadura del río Besaya, en el término de Cuchia. en el municipio cántabro de Miengo.

La situación concreta por coordenadas es la siguiente:

0'20'08" / 4325'55". I.G.C. 1/50.000 Hoja 34: Torrelavega.

Su peculiaridad es que se encuentra en la zona de expansión de la explotación de una cantera. La rapidez del avance del frente llevó a la práctica de una excavación de urgencia en el año 1982, dirigida por Carmen Gutiérrez Sáez y Federico Bernaldo de Quirós. La posterior ralentización de los trabajos de la cantera en este frente posibilitó que continuaran estas excavaciones en diversas campanas no continuas en un espacio de tiempo de tres años más, de 1983 a 1985.

La estratigrafía senalada por los excavadores es la siguiente, salvo error u omisión del autor de estas líneas:

Nivel I. Paquete sedimentario no homogéneo de tierra suelta de color marrón claro con intrusiones recientes, que contiene principalmente conchas de moluscos holocenos. especialmente con Monodonta lineata. Mytilus edulis. Patella vulgata y Ostrea edulis. En el apartado de la industria aparecen fragmentos de cerámica, restos liticos, óseos, pero, además, intrusiones recientes de botellas, restos metálicos y caucho quemado.

Nivel II. Es un nivel formado por una colada de arcilla casi estéril. pero de la que partes han sido removidas y, por tanto, está afectado por el nivel superior, presentanto el mismo tipo de materiales que el nivel 1 .

Bloque III. Amplio paquete de escasa matriz terrosa ya que está formado en su mayor parte por una acumulación de restos de molusco. fundamentalmente, de Litorina littorea y Patella vulgata. Este amplio paquete ha sido dividido por sus excavadores en los siguientes niveles:

Nivel III-1. La matriz terrosa que engloba el conchero es escasa y presenta un nítido color negro.

Nivel II-2. Capa de idéntico carácter que el nivel superior pero de color marrón y más arcilloso. Es de menor grosor y se pierde en algunas zonas de la excavación.

Nivel III-3. Nivel de caracteristicas similares al nivel III-1, tanto en consistericia, color y materiales.

Nivel III-4. Capa de arcilla plástica, con algunos cantos e industria de aspecto aziliense. Los moluscos, ampliamente representados en los niveles superiores, se reducen. 
Nivel III-4b. Nivel de matriz muy arcillosa y limpia que sólo se encuentra en la zona más externa de la cueva (sólo afecta a 3 metros de excavación) acunándose rápidamente hacia el interior. Sobre él se depositan los niveles de conchero.

Bloque IV. Nivel sin conchas de matriz arcillosa. Está dividido a su vez en niveles reducidos que representan una separación en algunas zonas por lentejones arcillosos. Los niveles citados son:

Nivel IV-1. Capa de matriz negra con algunos cantos bien diferenciada en la mayor parte de la cueva, aunque no es muy gruesa. Los restos de moluscos han desaparecido prácticamente en su totalidad. Una capa de arcilla muy pobre de materiales lo separa del nivel inferior.

Nivel IV-2. Es el nivel de mayor volumen de la estratigrafía y está formado por una capa de arcilla rojiza compacta con cantos redondeados. El grosor del nivel es menor en la boca de la cueva y va engrosando progresivamente hacia el interior del área excavada. Está separado del nivel inferior asimismo por una capa arcillosa con pocos materiales.

Nivel IV-3. Capa negra con cantos que se integra plenamente en el paquete global que forma el conjunto del nivel IV. Al contrario del nivel IV-2, está bien definido en la entrada de la cueva y va reduciéndose progresivamente hasta desaparecer en el fondo de la excavación. Está separado del nivel inferior por lentejones de arcilla compacta.

Nivel IV-4. Capa negra con cantos, similar al nivel superior. El comportamiento estratigráfico es igual a los anteriores.

Nivel $V$. Arcilla base, que se articula con bloques desprendidos del fondo de la cueva. Presenta muy pocos restos y todos, prácticamente. en la zona superior.

A la hora de considerar los materiales de los diferentes niveles del yacimiento, para el estudio se han tenido en cuenta las siguientes consideraciones de sus excavadores:

Se han desechado para el estudio los materiales de los niveles I y II, debido a encontrarse revueltos, totalmente el primero y en parte significativas y no distinguibles el segundo.

Los materiales que contiene el nivel III-4b, cuya formación parece responder a una avalancha erosiva que arrasó parcialmente los niveles inferiores, deben corresponder, por tanto, a los niveles parcialmente afectados por el nivel, es decir, a todos los del bloque IV pero no es posible distinguir a cuál o cuáles pertenecerian, por lo que también han sido abandonados para este estudio. 
Los materiales que se han encontrado en las coladas o lentejones de arcilla que separan los niveles del bloque IV, se han considerado heredados de los nive superiores, ya que la matriz amarilla y muy limpia, y el escaso grosor de estos "nivelillos", parecen hablar más de hiatos en la habitación y, por tanto, que los materiales que engloba, aparte de escasos, pertenecerian a la ocupación anterior.

Lo mismo se ha considerado con los materiales englobados en la parte superior del nivel $V$, con los mismos elementos de juicio que en el caso anterior.

\section{NOTAS HISTORIOGRÁFICAS}

La periodización primera y, como se ha demostrado, básica del final del Paleolítico ha sido la realizada por Breuil en 1913, teniendo como fundamento la industria ósea: Les subdivisions du Paléolithique Supérieur et leur signification. En esta obra se dividia el Magdaleniense en seis períodos (iuego ampliado a siete con el Protomagdaleniense o Magdaleniense 0). Entre éstas que pertenecen a fases tardias, añadiendo el Aziliense, los Magdalenienses $\mathrm{V}$ y VI.

La adaptación de esta periodización al Cantábrico fue realizada primeramente por Hugo Obermaier en El hombre fósil de 1925:

Magdaleniense $d$ : arpones de una hilera de dientes con protuberancia basal o perforación.

Magdaleniense e: arpones con dos hileras de dientes.

Magdaleniense $f$ : sin la presencia de arpones, resulta ser un antecedente del Aziliense.

Aziliense: arpones planos. Es un periodo intermedio (Epipaleolitico) entre el Magdaleniense y el Neolitico. Presenta una tradición magdale. niense empobrecida y algunas influencias africanas debido a la presencia de geométricos.

A partir de la década de los 50, una vez superado el parón parcial de la investigación producto de la guerra civil y los primeros años de la posguerra, se plantean unas líneas de investigación que vinculan el surgimiento del Magdaleniense y del Aziliense a influencias francesas. bien de la Dordoña-Perigord o de los Pirineos, sustituyendo las anteriores teorias africanistas (Santa-Olalla) y autoctonista (Obermaier, Carballo). 
Jordá (1958) limitó la presencia de la secuencia definida por Breuil a unas fases determinadas: Magdaleniense Inicial (paralelizable al Magdaleniense (II), un indeterminado Magdaleniense Medio, un Magdaleniense Superior (Magdaleniense $\mathrm{V}$ ) con arpones de una hilera de dientes y un Magdaleniense Final (Magdaleniense VI) con arpones de una y dos hileras de dientes. Además consideraba el Aziliense como originario de los Pirineos.

González-Echegaray, en 1960, en su primer estudio del Magdaleniense III-Inicial Cantábrico, señalaba la improcedencia de la separación de las fases finales del Magdaleniense teniendo sólo en cuenta las hileras de los arpones, y. vinculándolo al Paleolítico Superior, seguia manteniendo el origen cantábrico del Aziliense.

Tuvo gran importancia en la situación actual de los planteamientos de la investigación. no sólo sobre el Magdaleniense Superior y/o Final y el Aziliense. sino sobre la totalidad del Paleolítico Superior, el proyecto de investigación interdisciplinar desarrollado en la excavación de cueva Morin dirigida por González-Echegaray y Freeman y publicada en 1971 y 1973.

Junto a nuevas perspectivas de la investigación se produjeron cambios en las cuestiones cronoestratigráficas y tipológicas.

Una vez asumida la tipología de lista-tipo de Sonneville-Bordes/Perrot y sus aplicaciones estadisticas a partir de la publicación de los datos del yacimiento de Urtiaga por José Miguel de Barandiarán y SonnevilleBordes en 1964 y desarrollada una tipología ósea por parte de Ignacio Barandiarán en 1967, se produjeron avances gracias, entre otras cosas, al cambio en los métodos de excavación.

En este contexto entran los numerosos trabajos que sobre estos periodos de la Prehistoria del Cantábrico se han sucedido en la investigación cientifica hasta la actualidad. Entre ellas destacan las nuevas excavaciones realizadas y publicadas: Tito Bustillo por Moure, en 1975 y 1976, y por Moure y Cano, en 1985; Berroberria, por Ignacio Barandiarán, en 1979; Los Azules, por Fernández-Tresguerres, en 1980; Las Caldas, por Corchón, en 1981; Rascaño, por González-Echegaray e Ignacio Barandiarán, en 1981; Ekain, por Altura y Merino, en 1984; Erralla, por Altuna, Baideón y Mariezkurrena, en 1985; La Riera, por L. G. Strauss y G. A. Clark, en 1986, o el estudio de los materiales de una remoción clandestina de Laminak II, por Arribas y Berganza, en 1988. Asimismo se han realizado numerosas revisiones de excavaciones antiguas: La Paloma, por Hoyos y otros, en 1980; El Pendo, por González-Echegaray y otros, en 1980; El Castillo, por Cabrera, en 1984, y la práctica totalidad 
de los yacimientos con niveles de este periodo de Vizcaya y Guipuzcoa, por Fernández-Eraso, en 1985.

En la última monografia de la cueva de Tito Bustillo (Moure y Cano, 1976) se señalaba la reducción de los periodos tardíos del Magdaleniense a dos fases sin solución de continuidad entre ellas y el Aziliense: un Magdaleniense Superior, sin elementos caracteristicos del Aziliense, y uno Final con un proceso de microlitización y aparición abundante de elementos azilienses (puntas, «disquitos raspadores», raspadores unguiformes...).

En esta misma línea se sitúa el trabajo sintético del Groupe de Travail de Préhistoire Cantabrique que en 1977 señala que la industria del periodo Tardiglaciar en la Cornisa Cantábrica presenta dos tendencias claras, una es la microlitización progresiva de la industria litica y la otra la reducción de los tipos óseos; no siendo fácil distinguir el Magdaleniense Superior del Final. Además se señala la existencia de dos facies cronológicamente contemporáneas distinguidas por el predominio del índice de buril en una y del indice de raspadores en otra.

Pero fundamentalmente hay que tener en cuenta los trabajos de síntesis realizados por Fernández-Tresguerres, El Aziliense en las provincias de Asturias y Santander de 1980, y la reciente de González Sainz en El Magdaleniense Superior-Final de la región cantábrica de 1989.

Fernández-Tresguerres supera decididamente las lineas teóricas que consideraban por motivos "estéticos" al Aziliense como un período de decadencia o desintegración de otro de máximo “desarrollo cultural» significado en un arte, tanto mobiliar como parietal, de gran valor artístico. Todo lo contrario, el Aziliense responde a una evolución hacia el (sic) "utilitarismo y simplicidad" producto de la depuración de la experiencia obtenida en el Magdaleniense.

Algunas de las ideas desarrolladas en su obra sobre el Aziliense son las siguientes:

- En la industria lítica los raspadores se caracterizan por la presencia de tipos cortos y anchos. Los buriles en relación con el Magdaleniense descienden en porcentaje de forma drástica. Las hojitas de dorso, en cambio, aumentan considerablemente, tendencia entrevista ya en el Magdaleniense Final. Las puntas azilienses están presentes en proporciones bajas, por debajo del $10 \%$. En algunos casos han sido sustituidas por "microgravettes" como es el caso de Morin. Los microlitos sólo están presentes en bajas proporciones dentro de la cornisa cantábrica en el 
Pais Vasco y en la zona oriental de Cantabria. Las piezas pertenecientes al "sustrato» presentan una proporción relativamente importante.

- La industria ósea está caracterizada por dos tipos de "fósil-guía": los arpones planos de una o dos hileras de dientes con perforación basal en forma de ojal, con origen en la región pirenaica (La Vache), y los punzones.

- El arte, sólo mobiliar, está representado por cantos pintados y grabados y huesos grabados.

Por último, González Sainz en su tesis realiza una sintesis de todos los datos conocidos para este periodo, encuadrándolos en las fases anterior y posterior. Magdaleniense Inferior y Medio y Aziliense. De su obra se pueden entresacar las siguientes ideas:

- El período Magdaleniense Superior-Final está cronológicamente situado entre el $13.000 \mathrm{~B}$. P., en que aparecen los primeros arpones de una hilera de dientes, y el 10.800 B. P., en que están generalizados los arpones planos.

- La industria lítica está sujeta a unas mismas tendencias técnicas pero se adapta al condicionamiento geográfico de las materias primas, lo que supone una variación en los porcentajes tipologicos por regiones, mayor presencia de raspadores unguiformes y puntas azilienses en las zonas occidentales y, al contrario, de raspadores simples y «microgravettes" en las zonas orientales, mayor proporción de buriles en el Este que en el Oeste en detrimento de la de raspadores. El índice laminar aumenta en las fases iniciales del periodo para estancarse o descender en las fases avanzadas. Lo mismo ocurre con los buriles. La industria microlaminar presente en porcentajes altos en todo el Magdaleniense aumenta en las últimas fases del Magdaleniense Superior-Final.

- La industria ósea supone un gran florecimiento en la fase plena de este periodo produciéndose un enrarecimiento en las fases últimas. El "Magdaleniense Reciente" está caracterizado por la aparición de arpones de una hilera de dientes. despues de un (sic) "horizonte de protoarpones" del Magdaleniense Medio. En torno al 12.400-12.000 B. P. hacen su aparición los arpones de doble hilera de dientes, perviviendo los de una hilera. La generalización del arpón aplanado aziliense es producto de una difusión rápida de la región de los Pirineos.

- Existe una vinculación entre la alta proporción de buriles y el gran desarrollo de la industria ósea en esta fase. Las diferencias en los porcentajes en la zona occidental responde a adaptaciones tipológicas a los condicionantes de la industria sobre hojitas, y especialmente de las puntas de dorso, en un momento de disminución y enrarecimiento de la industria ósea en la fase final del periodo. 
- En los aspectos relativos a la explotación del medio se indica en las primeras fases una mayor "especialización" en los inicios del Magdaleniense Superior-Final de las formas de subsistencia y una gran movilidad de los grupos humanos. por ejemplo. en el aprovisionamiento de las materias primas. En los periodos finales se produce una diversificación del aprovechamiento del medio (marisqueo y aumento de la pesca) y la restricción de la movilidad del aprovisionamiento.

\section{ESTUDIO DE LOS MATERIALES}

La caracteristica básica y definitoria de la industria lítica de la totalidad de los niveles. tanto con conchero (Bloque III) como sin él (Bloque IV). del yacimiento de La Pila es el fuerte porcentaje de útiles sobre laminilla. principalmente de dorso abatido.

En todos los niveles. con la única excepción del III-4 en donde es ligeramente inferior. la proporción es superior al $45 \%$ llegando al máximo en el nivel $111-2$ con $60.43 \%$. Como se puede ver. presenta porcentajes muy elevados y, por tanto. subsumen al resto de la industria a una representatividad reducida. Además. las proporciones de hojitas de todos los niveles son muy homogeneas. con la excepción del maximo y del minimo (niveles $\| I-2$ y $|1|-4)$ que. por cierto. son los niveles con menor cantidad de útiles. lo que constituye una distorsión importante de las proporciones.

La homogeneidad. que se situa en torno al $49.45 \%$ (que es la media de todos los niveles). se produce tanto en el bloque III (media de $48.28 \%$ ) que los del bloque IV (50.06\%). media ligeramente superior: sólo parece darse la eventualidad de una mayor proporción en los niveles del bloque IV, en el que sólo los dos inferiores sobrepasan el $50 \%$.

Por lo tanto. tendremos que considerar en adelante que los análisis y tendencias que se efectuen de la industria litica estarán inclusos en un conjunto marcadamente homogeneo en su aspecto tipológico por una mayoria abrumadora de útiles sobre laminilla. especialmente con dorso abatido.

Nivel IV-4

Es el nivel fértil estratigráficamente inferior. que tiene un total de 173 útiles. El conjunto lítico se caracteriza. como se ha dicho con anterioridad. 

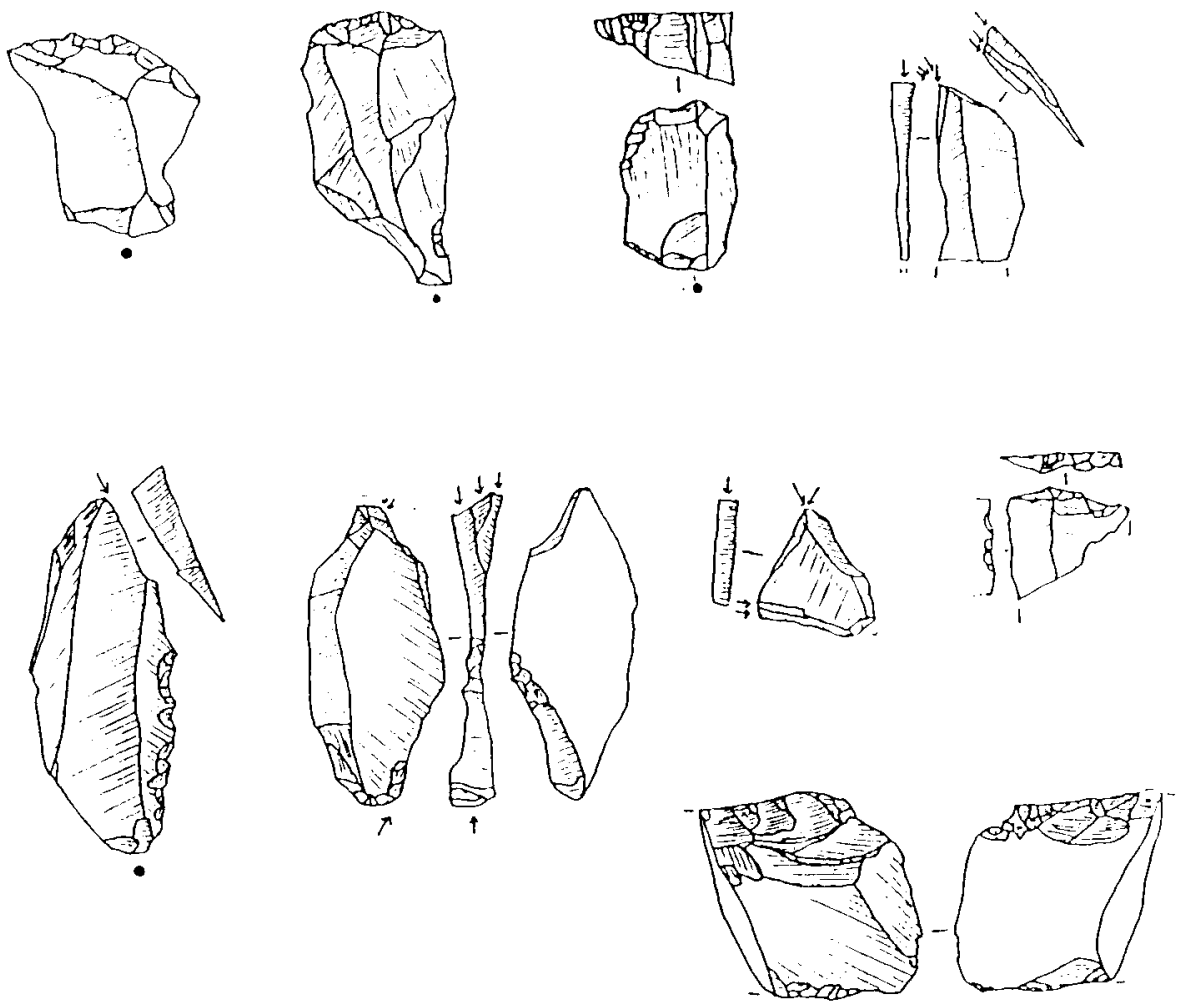

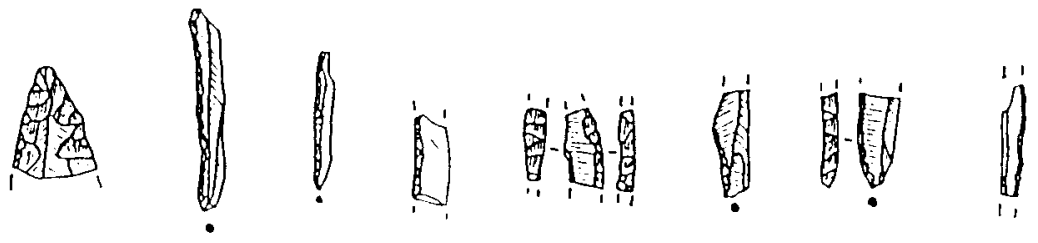

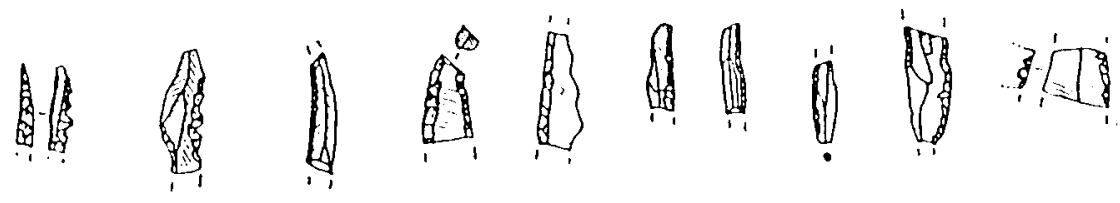

NIVEL IV-4. 

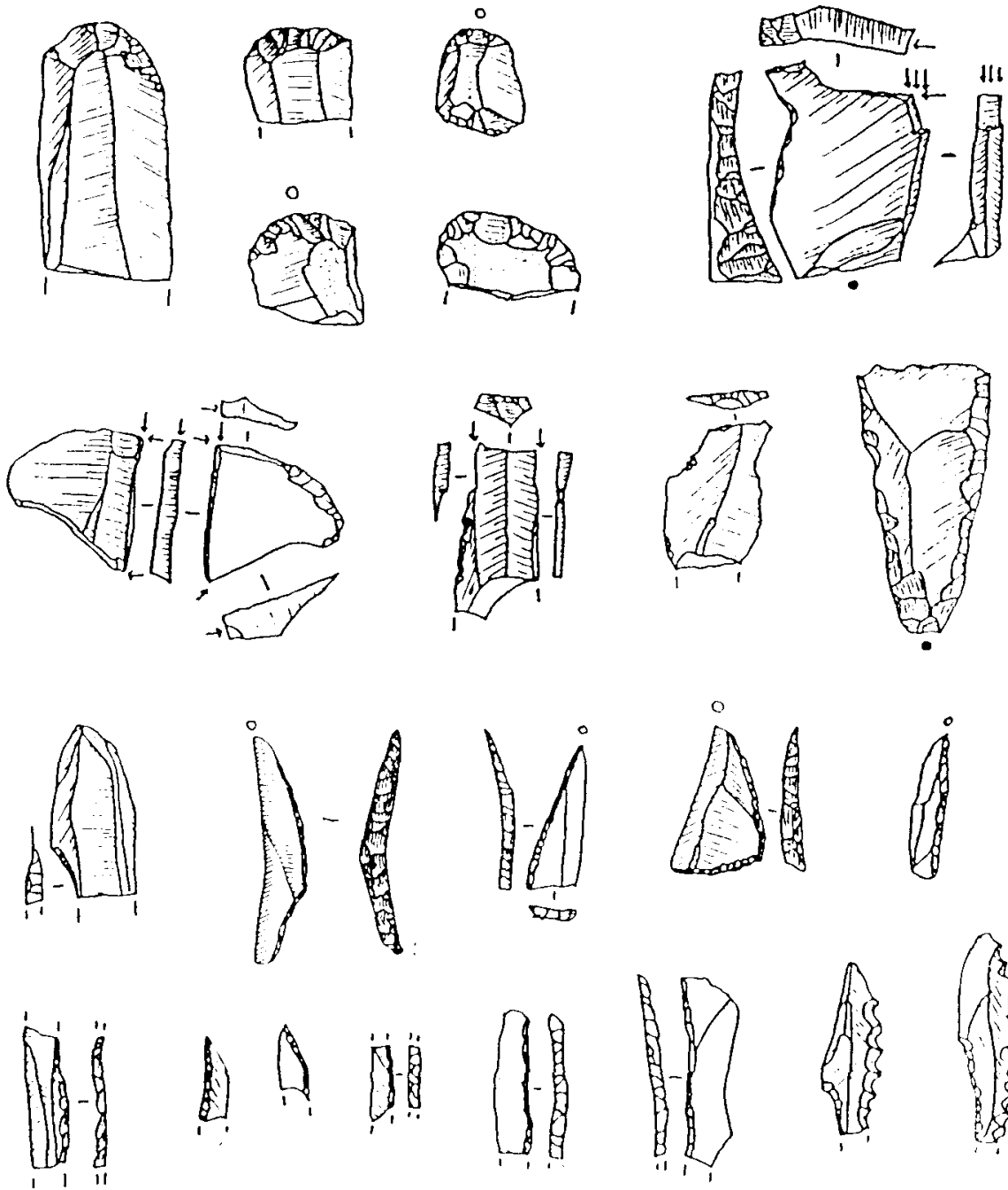

1) 9
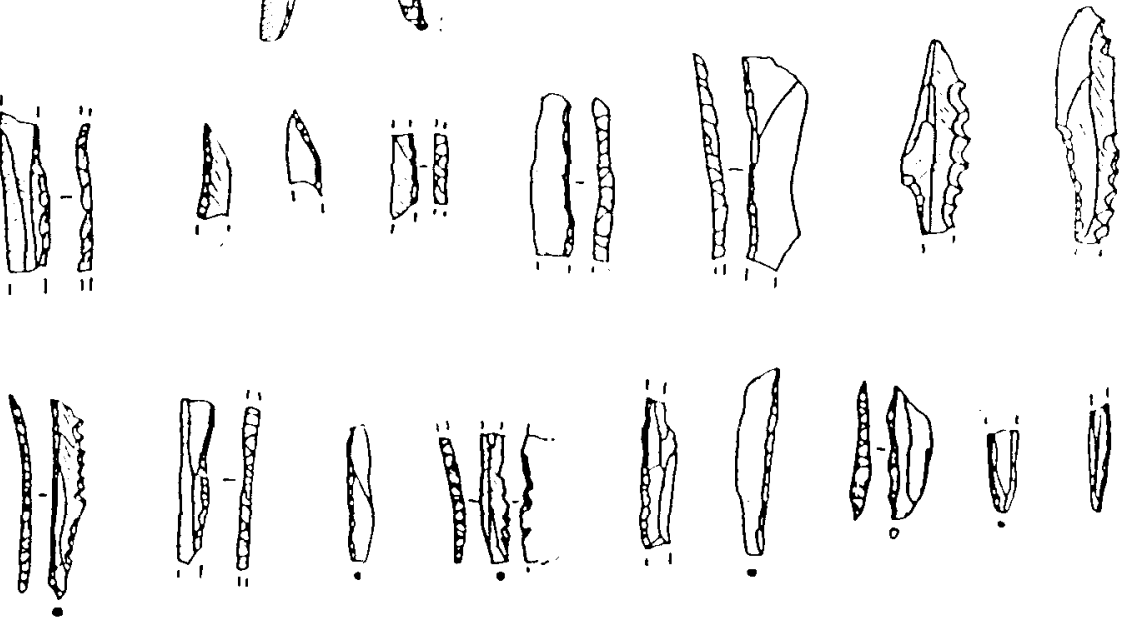

圊

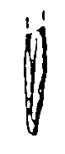

NIVEL IV-3. 
por un predominio de la industria sobre hojitas $(51.45 \%)$. pero además los comportamientos de la industria de este nivel son:

Los raspadores estan escasamente representados ya que sólo alcanzan el $5.78 \%$. Los tipos mayoritarios son los realizados sobre lasca y los simples sobre lámina.

Los útiles compuestos y los perforadores están muy débilmente representados.

Los buriles son más numerosos que los raspadores (11.56\%). siendo la mayoria diedros (IBdr: $55 \%$ ), entre los que predominan los realizados sobre rotura o plano natural. aunque los realizados sobre truncadura no son escasos (IBtr: $35 \%$ ).

Las truncaduras tienen una presencia equiparable a la de raspadores $(5.20 \%)$. no destacando ninguna de sus variedades.

Las piezas retocadas sobre uno o dos bordes es bastante elevada ya que alcanza un $11.56 \%$. de la que una proporción muy baja se puede clasificar como "lámina magdaleniense" $(0.58 \%)$.

Las piezas incluidas en el "sustrato" presentan una proporción tampoco desdenable $(11,56 \%)$. de las que destacan las piezas esquirladas $(3.47 \%)$ y las piezas de muesca $(3.47 \%)$.

La industria sobre hojitas es mayoritariamente perteneciente al tipo número 85 de la lista de S-B/P $(36.42 \%)$. La mayor parte son fragmentos. aunque un buen número esta apuntado $(6.36 \%)$.

Del resto de industria sobre laminilla de dorso destacan las denticuladas (tipo numero 86 de la lista de $\mathrm{S}-\mathrm{B} / \mathrm{P}$ ) que presentan una proporción general de $6.82 \%$ y de $12.64 \%$ del total de hojitas. El resto no presenta entidad.

Nivel IV-3

El nivel inmediatamente superior al anterior responde a las siguientes líneas de comportamiento. con 164 útiles:

Los raspadores presentan una proporción también baja $(8.54 \%)$ aunque superior a la del nivel IV-4. Mayoritariamente son simples sobre lámina y. en menor proporción. están realizados sobre lasca.

La proporción de buriles es baja $(6.10 \%)$. siendo muy mayoritarios los diedros ( $4.88 \%$ del total y $80 \%$ de todos los buriles). 
No existen ni útiles compuestos ni perforadores.

Las truncaduras presentan una proporción también baja $(3.66 \%) \sin$ que predomine ningún tipo entre ellas.

La proporción de piezas retocadas es alta. alcanza el $12.20 \%$. superior a la proporción de buriles y de raspadores. Las "láminas magdalenienses". con retoque escamoso. no estan presentes: si. en cambio y de modo testimonial. las láminas apuntadas con retoque simple $(1.93 \%)$.

Las piezas pertenecientes al "sustrato» tambien presentan una proporción alta $(12.20 \%)$. manteniendo su primacia las piezas esquirladas $(6.71 \%)$ y las piezas de muesca $(3.66 \%)$.

La representación de las piezas de dorso grande está formada exclusivamente por la presencia testimonial de las puntas azilienses $(1.83 \%)$. reduciéndose a la minima expresión si solo consideramos las piezas "tipicass $(0,61 \%)$.

La industria sobre hojitas $(54.88 \%$ ) es la de más elevada proporción. y predomina el tipo numero $85(44.51 \%$ del total y $78.49 \%$ de todas las laminillas). De éstas destaca la proporción alta de las laminillas de dorso apuntadas $(10.37 \%)$ y que los dobles dorsos representan la minima expresión $(0.61 \%)$.

La proporción de las laminillas de dorso denticuladas es relativamente alta $(5.49 \%$ del total y $9.68 \%$ de todas las laminillas). asi como. en cierta manera. la de hojitas retocadas $(3.05 \%)$.

Nivel IV-2

El comportamiento del nivel de mayor potencia estratigráfica y de mayor riqueza (929 piezas retocadas) es el siguiente:

La proporción de raspadores es alta (17.01\%). Predominan. siguiendo la tónica general. los simples y sobre lasca. El resto de tipos, salvo los raspadores circulares $(1.29 \%)$, sólo aparecen de manera testimonial: carenados, en hocico. unguiformes.

Los útiles compuestos y perforadores se mantienen en una proporción muy baja $(1,51 \%$ y $0,97 \%$, respectivamente).

Asimismo, la de buriles es muy baja (5,92\%), predominando los diedros sobre los de truncadura $(3,38 \%$ del total y $58,18 \%$ de todos los buriles). 

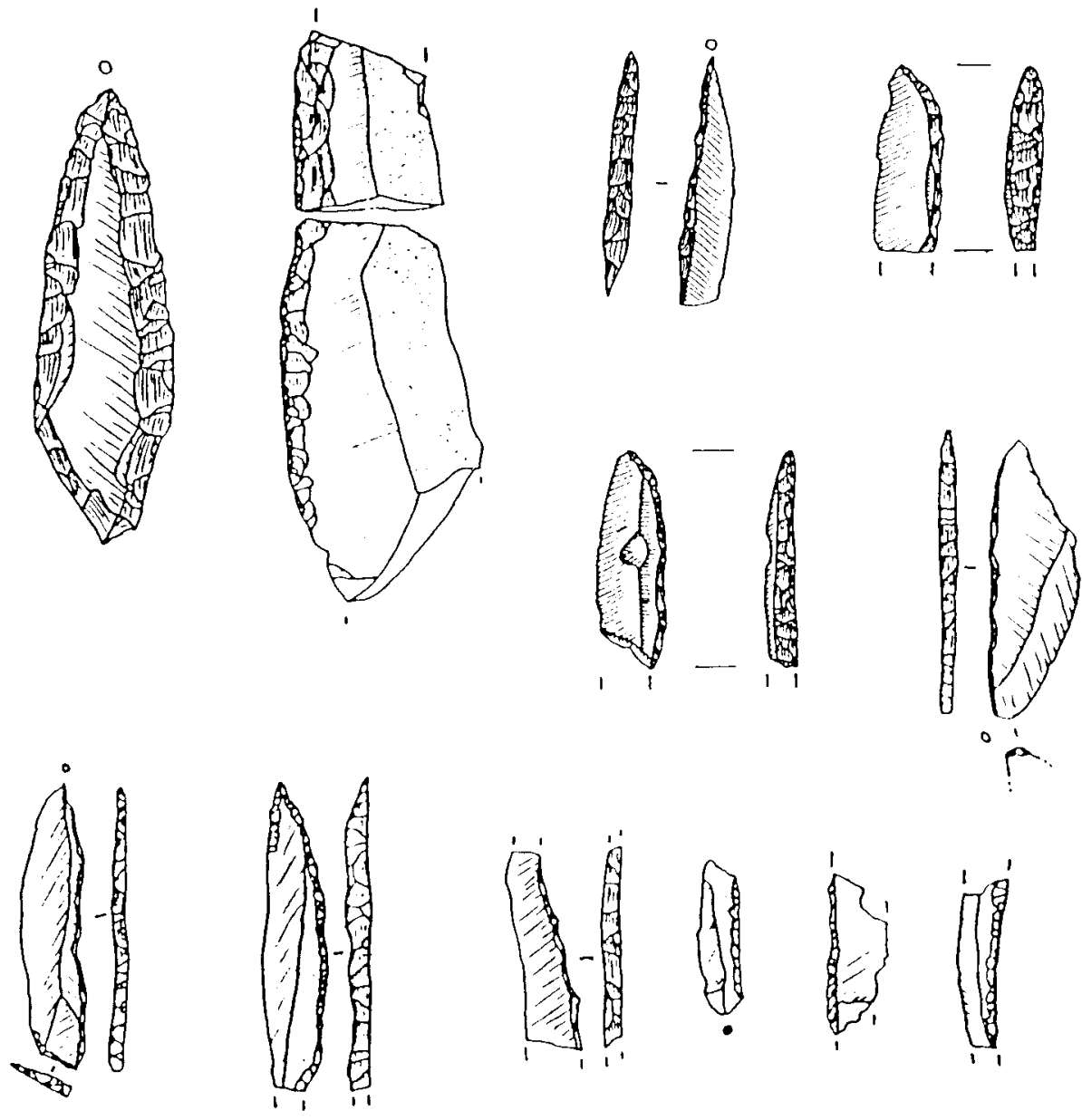

-
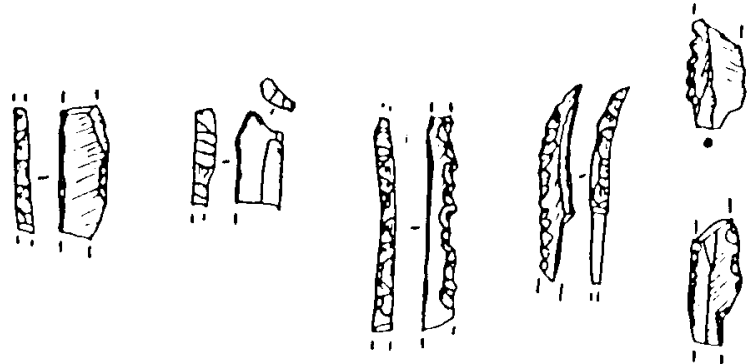

NIVEL IV-2. 

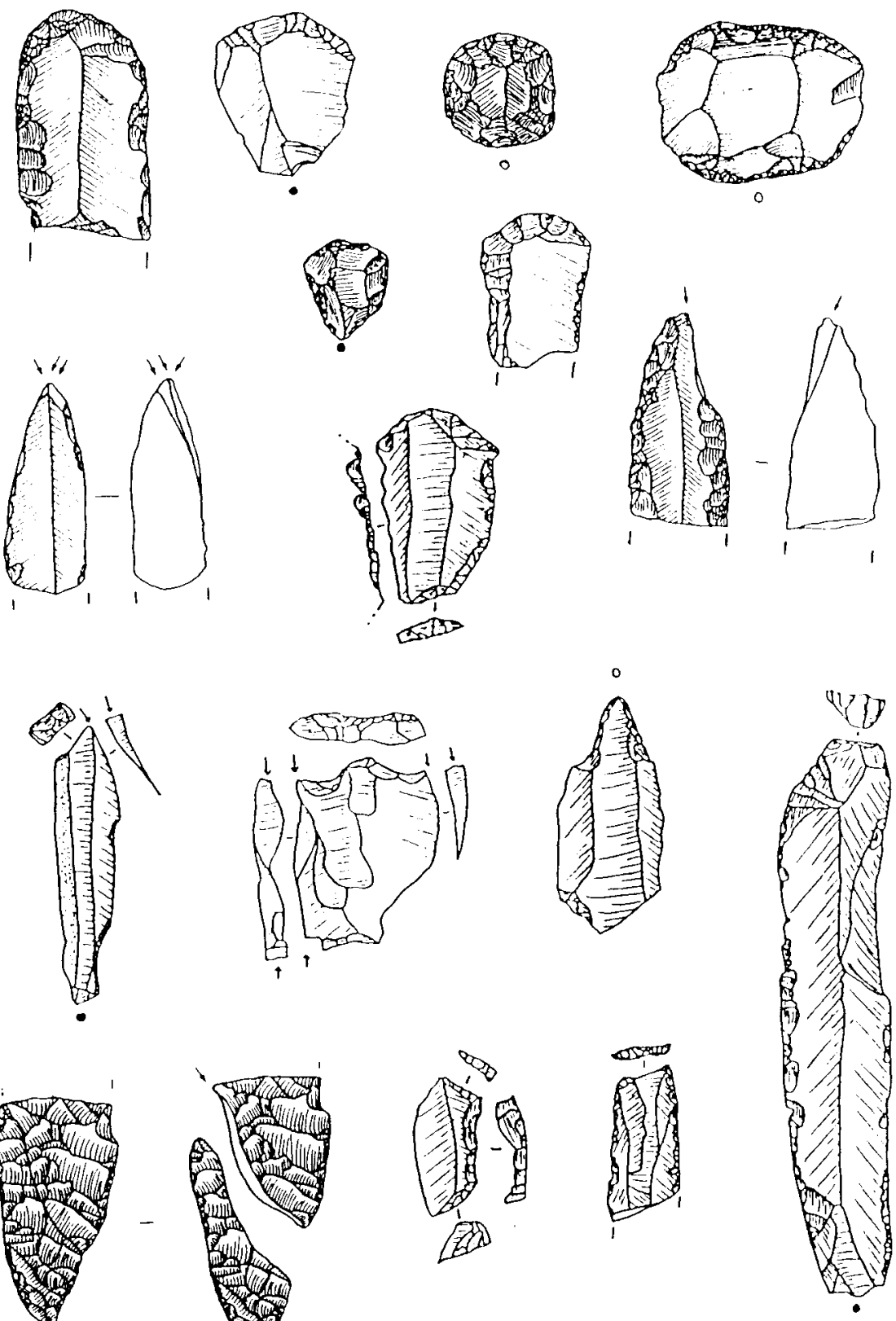

NIVEL IV-2 
Las truncaduras son también pocas $(4,95 \%)$.

La proporción de piezas con retoque simple es muy baja también en relación con los niveles anteriores $(7,43 \%)$, porcentaje en el que se incluye la existencia muy reducida de las "láminas magdalenienses" $(1,18 \%)$.

Las piezas del "Sustrato" están representadas por una proporción similar aunque ligeramente inferior a los niveles anteriores, siguen manteniéndose las piezas esquirladas como las principales del grupo con un $5,49 \%$.

En las piezas de dorso destacan las puntas azilienses $(3,01 \% \circ$, con la definición restringida, $1,51 \%$ ), y la aparición testimonial de las "microgravettes".

En la industria de hojitas $(49,19 \%)$, las de dorso suponen un $38,00 \%$, de las que las apuntadas alcanzan un $7,21 \%$ y las de doble dorso sólo son testimoniales.

El resto de hojitas están presentes en porcentajes muy bajos, destacando las hojitas con fino retoque $(3,88 \%$ y $6,16 \%)$ y las de dorso denticuladas $(3,44 \%$ y $6,57 \%)$.

\section{Nivel IV-1}

El nivel superior del bloque sin conchero presenta un conjunto lítico de 325 útiles con un comportamiento similar al nivel anterior:

Los raspadores están presentes en una proporción alta $(19,08 \%)$, predominando también los simples y los realizados sobre lasca. El resto de tipos tienen poca importancia en porcentaje pero una cierta variedad: unguiformes, circulares y sobre lasca y lámina retocada.

Los útiles compuestos, los perforadores y las truncaduras se mantienen en proporciones bajas.

Los buriles son también escasos $(4,62 \%)$ y predominan muy netamente sobre los de truncadura y entre ellos destacan los realizados sobre rotura o plano natural.

Las truncaduras están representadas por un porcentaje muy bajo $(3,69 \%)$. 

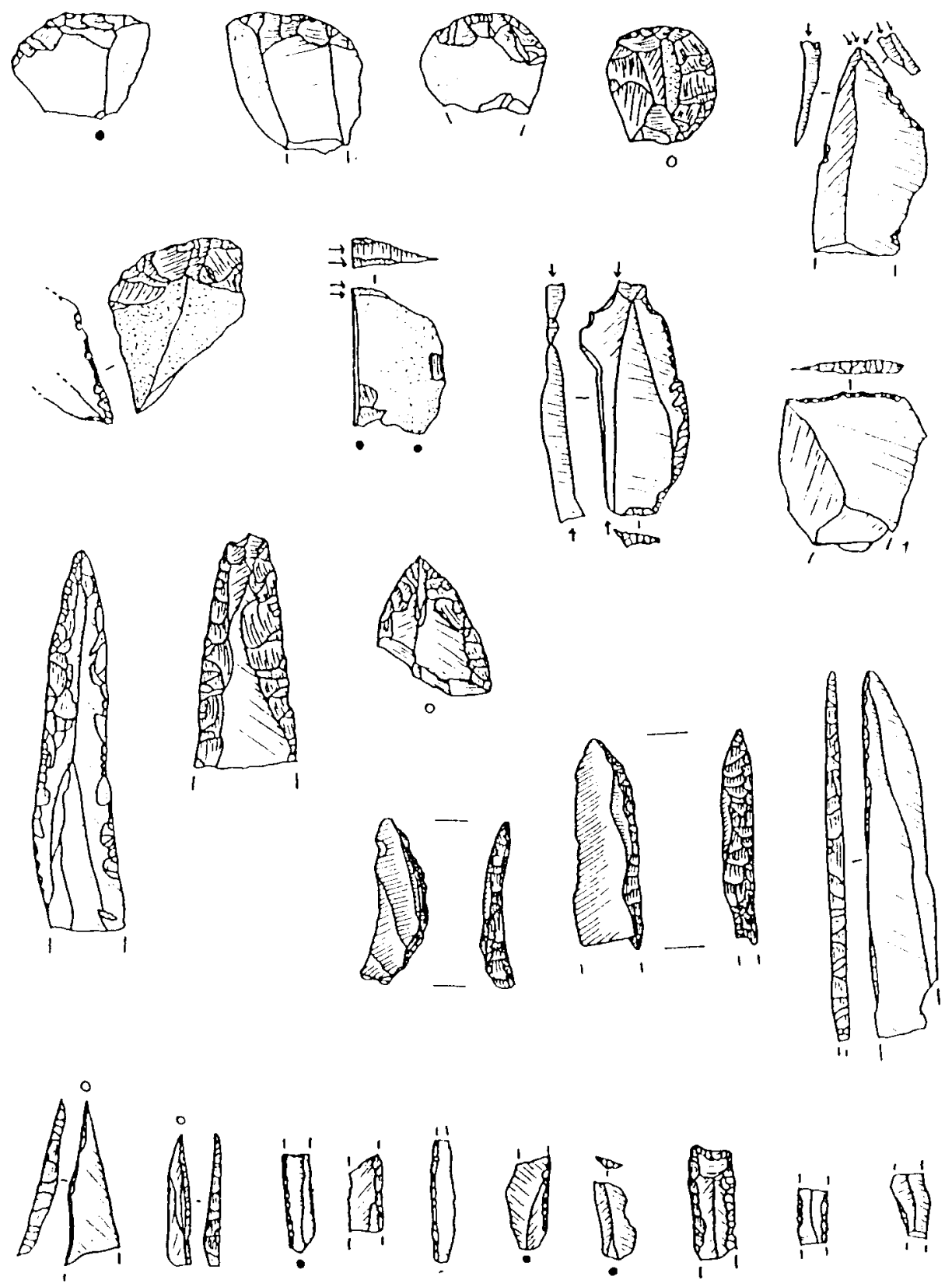

NIVEL IV-1. 

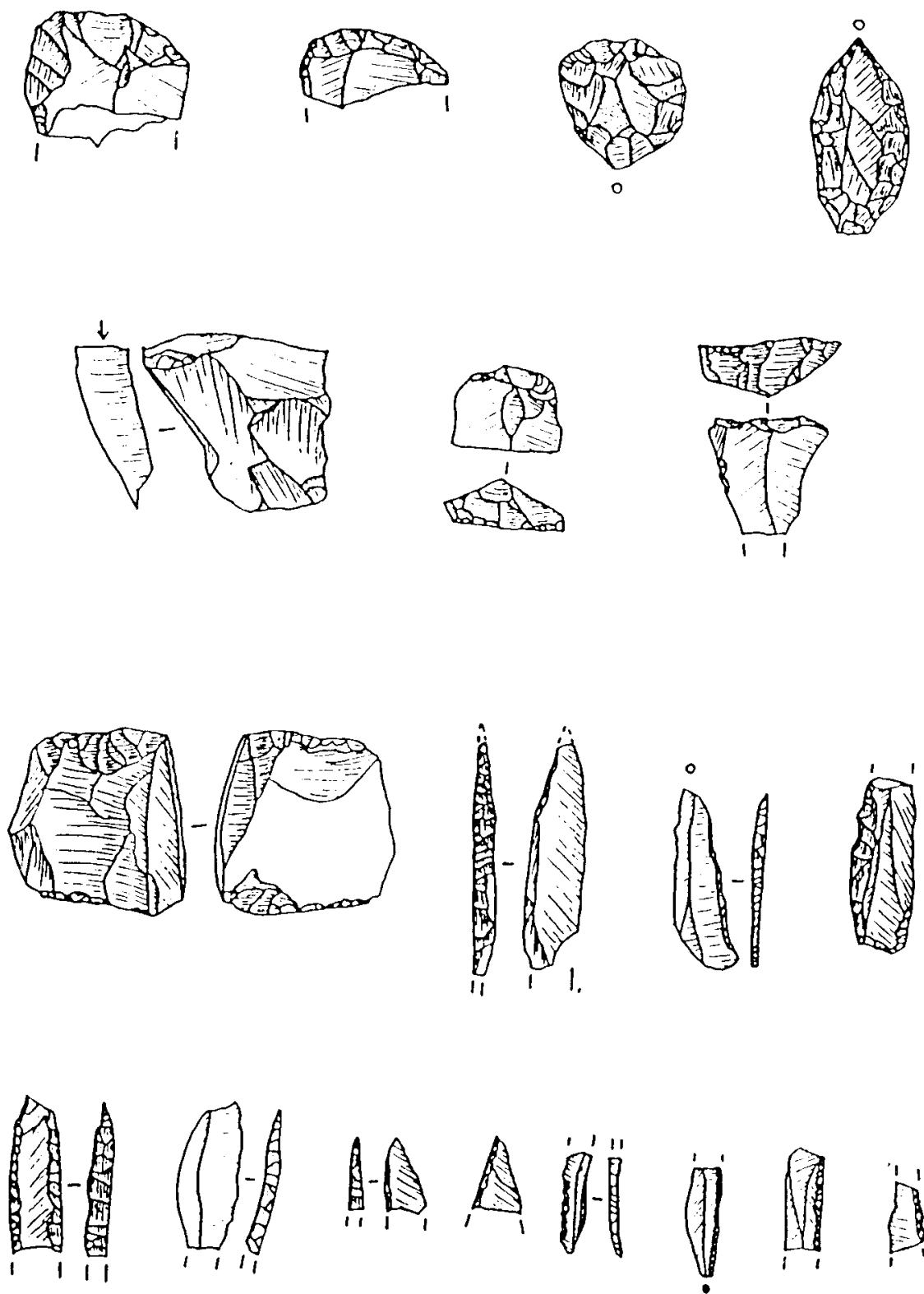

1
18

NIVEL III-4. 
Las piezas con retoque simple se mantienen en una proporción baja $(7,08 \%)$, de la que destaca la relativamente alta proporción de láminas magdalenienses $(2,15 \%)$.

El «sustrato» se mantiene en su proporción normal $(6,77 \%)$, destacando asimismo las piezas esquirladas $(5,23 \%)$.

En las piezas de dorso las puntas azilienses presentan una proporción relativamente más elevada $(6,46 \%)$, aunque en sentido estricto son sólo un $2,77 \%$. Las "microgravettes" son testimoniales.

De la industria sobre laminillas $(49,54 \%)$ son las hojitas de dorso las mayoritarias $(40,92 \%)$, de las que las apuntadas son un $5,54 \%$, mientras que las piezas de doble dorso son muy escasas $(0,62 \%)$.

Del resto de industria sobre laminilla sólo destacan las retocadas con "fino retoque" $(4,31 \%)$.

\section{Nivel III-4}

El nivel inferior del bloque III con conchero de este yacimiento está configurado por el siguiente conjunto lítico, que está distorsionado porque contiene sólo 63 útiles.

Los raspadores tienen una proporción muy alta $(22,22 \%)$, es la más alta de toda la estratigrafía, siendo mayoritario el tipo simple tanto sobre lasca como sobre lámina.

Aunque el porcentaje es el más alto de todos los niveles $(3,17 \%)$, los útiles compuestos están muy poco representados. Lo mismo ocurre con los perforadores.

Los buriles tienen también una proporción muy baja $(6,35 \%)$, son todos diedros y casi todos están realizados sobre rotura o plano natural.

Las piezas truncadas se mantienen en una proporción baja $(4,76 \%)$, y sigue sin destacarse ningún tipo entre ellas.

Asimismo, las piezas retocadas con retoque simple se encuentran en una proporción más que modesta $(6,36 \%)$.

Las piezas del "sustrato" presentan también un porcentaje bajo y están compuestas sólo por piezas esquirladas.

Las piezas de dorso son únicamente puntas azilienses típicas, lo que señala para este tipo un porcentaje medianamente alto $(6,46 \%)$. 
En la industria sobre laminillas $(42,86 \%)$ predominan las hojitas de dorso $(34,92 \%)$, entre las que se entresacan la proporción alta de laminillas de dorso apuntadas $(6,36 \%)$ y la baja de doble dorso $(4,76 \%)$.

Del resto de industria sobre laminilla destacan las hojitas de dorso truncadas $(4,76 \%)$.

Nivel III-3

El siguiente nivel está compuesto por una industria muy similar a la anterior, con 350 piezas retocadas:

Los raspadores presentan una proporción muy alta $(18,73 \%)$, los tipos más numerosos son los raspadores simples y los raspadores sobre lasca, aunque en el primer caso están también mayoritariamente realizados sobre lasca. Además tienen cierta importancia los circulares $(2,13 \%)$ $y$ unguiformes $(1,52 \%)$.

Las proporciones de útiles compuestos y de perforadores son testimoniales.

Los buriles se mantienen en porcentajes muy bajos $(3,71 \%)$, y siguen siendo mayoritariamente diedros aunque, en este caso, no domina ningún tipo.

Las truncaduras se mantienen en la tónica acostumbrada con una proporción baja $(4,78 \%)$.

Las piezas retocadas de modo simple presentan una proporción muy baja $(3,65 \%)$.

Por contra, las piezas del "sustrato" presentan un porcentaje alto $(9,43 \%)$, pero manteniendo la primacía de las piezas esquirladas $(6,38 \%)$.

Las puntas azilienses se presentan en una proporción relativamente alta $(7,55 \%)$, que en sentido estricto se reduciría a un 3,65\%.

La industria de laminillas está representada mayoritariamente por las hojitas de dorso $(33,43 \%)$, en las que destacan las apuntadas $(5,43 \%)$ $y$ las de doble dorso $(4,53 \%)$.

Del resto de la industria sobre laminilla están las hojitas con ufino retoque» $(5,14 \%)$ y las hojitas de dorso truncadas $(3,32 \%)$. 


\section{La tipología del utillaje lítico del yacimiento de La Pila}
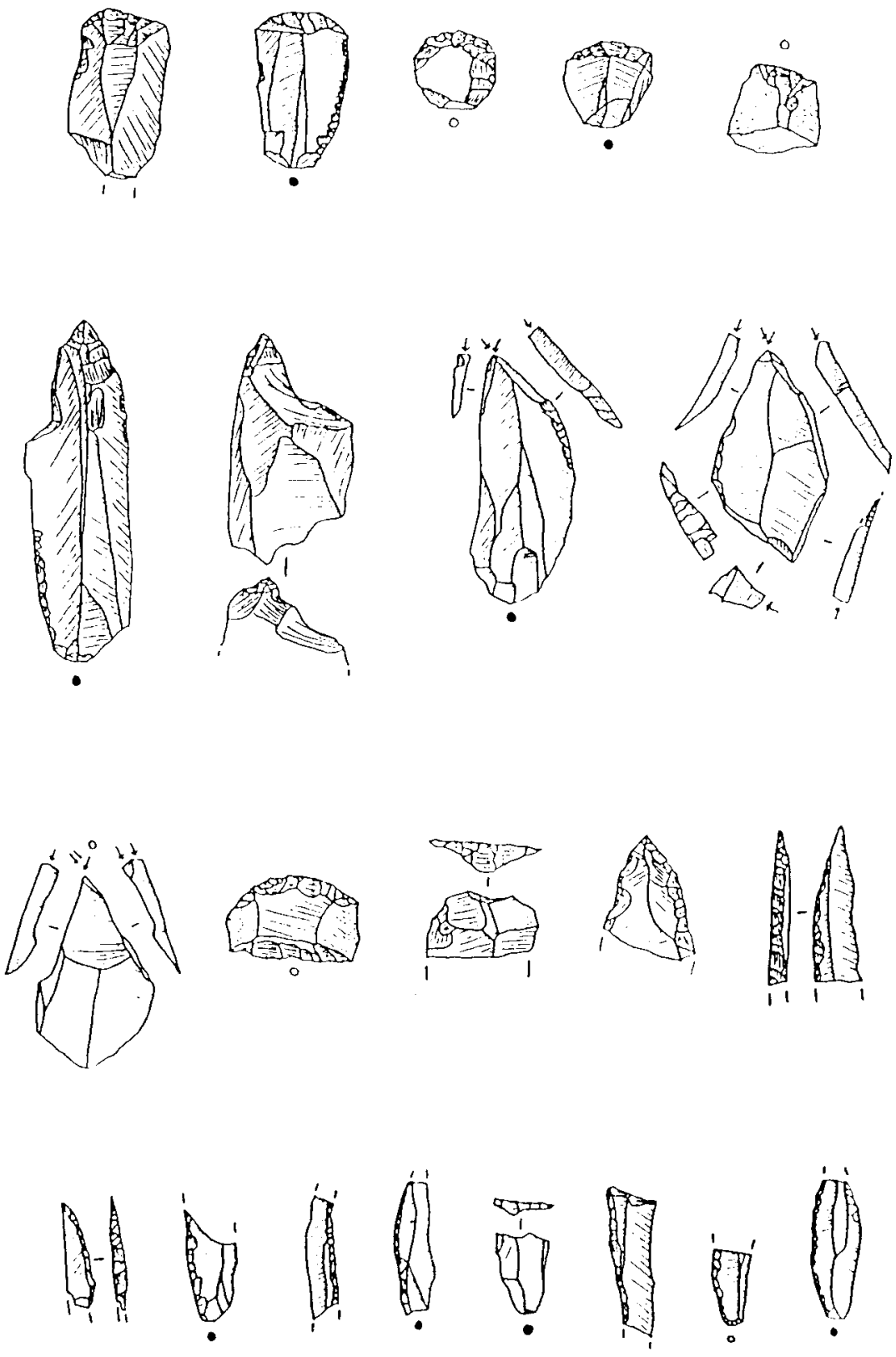

NIVEL III-3. 

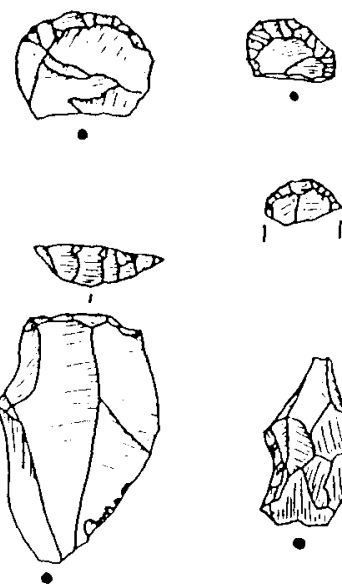

1
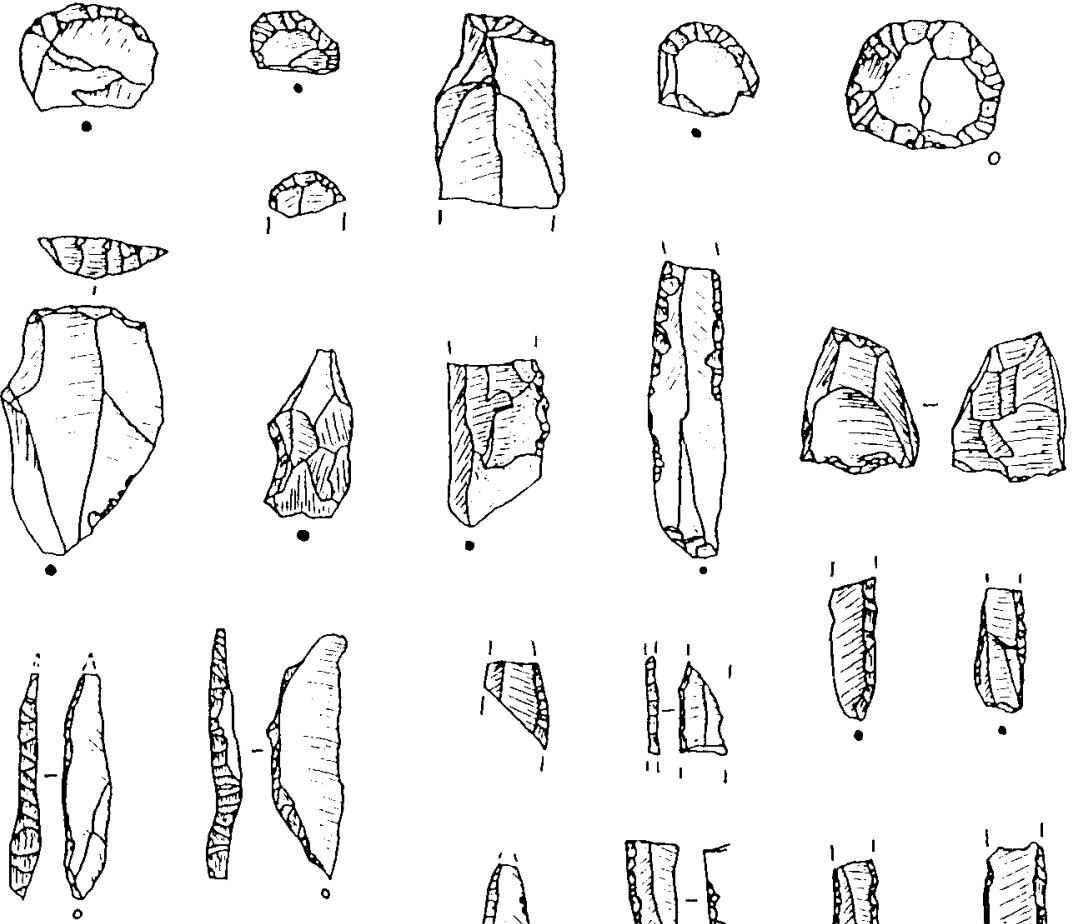

in
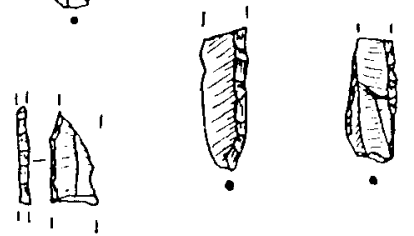

8
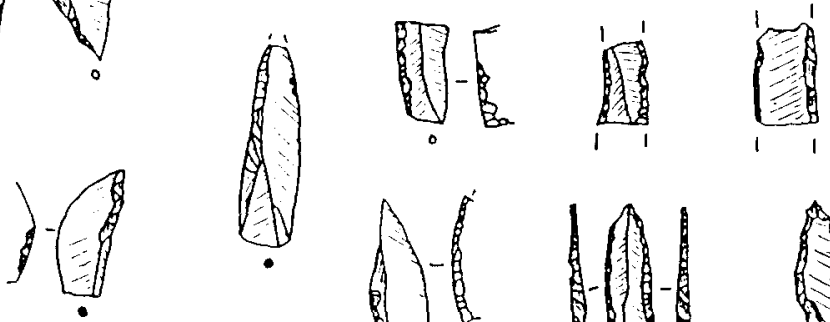

A
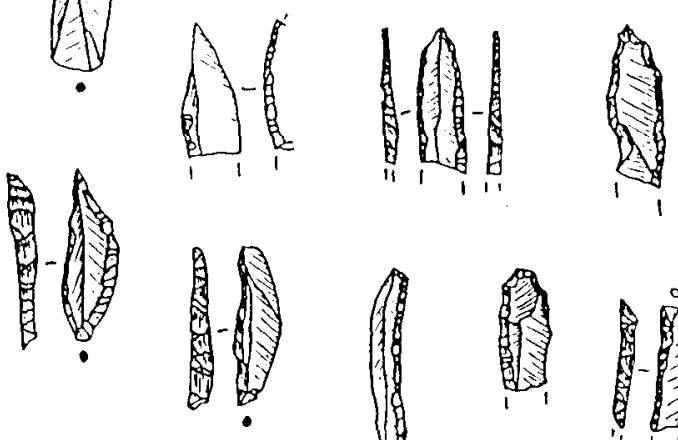

且
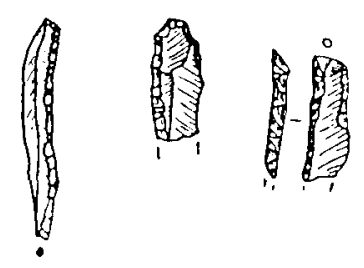

NIVEL III-2. 
Nivel III-2

Este nivel es el que menos piezas tiene, sólo 58 , y se desglosa de la siguiente manera:

El porcentaje de raspadores es alto $(17,24 \%)$, predominan los raspadores sobre lasca $(17,24 \%)$, los simples $(5,17 \%)$ y los circulares $(3,45 \%)$.

No han aparecido útiles compuestos, buriles ni perforadores.

Las truncaduras y las piezas con retoque simple aparecen testimonialmente.

En cambio, las piezas del "Sustrato" presentan un porcentaje alto $(13,79 \%)$, entre las que destacan las piezas esquirladas y las piezas de muesca, ambas con un 5,17\%.

De las puntas de dorso están representadas por "microgravettes" $(3,45 \%)$ y puntas azilienses típicas $(1,72 \%)$.

Entre la industria sobre laminillas es importante señalar que las hojitas de dorso apuntadas alcanzan un $15,52 \%$ y que las piezas con doble dorso alcanzan una proporción muy elevada $(20,69 \%)$. Además tienen un porcentaje significativo las hojitas de dorso truncadas con un 5,17\% del total de útiles del nivel y un $8,33 \%$ de todas las hojitas.

Nivel III-1

El último nivel superior intacto, con 301 útiles, presenta el siguiente comportamiento de su utillaje lítico:

En los raspadores se mantiene el alto porcentaje, siendo los tipos más numerosos los simples, principalmente sobre lasca $(6,31 \%)$, los unguiformes $(2,99 \%)$ y los realizados sobre lasca $(2,66 \%)$.

No hay útiles compuestos y los perforadores son muy escasos.

Los buriles presentan, en cambio, un porcentaje muy bajo, con predominio de los buriles diedros, pero sin que, dentro de éstos, destaque ningún tipo.

La proporción de truncaduras es muy baja $(2,66 \%)$, sin el predominio de ningún tipo. 
Las piezas retocadas con retoque simple están presentes en este nivel con un porcentaje medio $(6,98 \%)$, en las que sólo de forma testimonial aparece "retoque magdaleniense".

El "sustrato" tiene una proporción elevada $(11,30 \%)$, continuando siendo mayoritaria la pieza esquirlada.

De las piezas de dorso es alto el porcentaje de puntas azilienses (7,31\%), en sentido restringido sólo sería un 3,99\%; junto a éstas aparece una débil proporción de "gravettes».

Por último, en la industria sobre laminillas, en concreto en las hojitas de dorso $(35,22 \%)$, destaca el porcentaje alto de hojitas de dorso apuntadas $(11,96 \%)$ y el altísimo de las de doble dorso $(10,96 \%)$. De resto de industria lítica, sólo presentan proporciones relativamente altas las hojitas con "fino retoque", con un $7,37 \%$.

\section{COMPARACIÓN POR GRUPOS TIPOLÓGICOS}

En el estudio de los grupos o índices tipológicos, tanto tradicionales como nuevos, han resultado especialmente significativos varios de ellos.

El primer índice significativo es el que pone en relación los raspadores y los buriles.

El conjunto de raspadores presenta una distinción clara entre los dos niveles inferiores de la secuencia y el resto de niveles. Tanto el nivel IV4 como el IV-3 presenta un porcentaje de raspadores inferior al $10 \%$. En cambio, el resto de los niveles, todos los del Bloque III y los superiores del Bloque IV, presentan unas proporciones de raspadores entre el $15 \%$ y el $20 \%$, con la excepción del nivel III-4 que supera ligeramente el límite superior.

Los buriles presentan la tendencia contraria. Todos los niveles están caracterizados por una débil proporción (entre el $3 \%$ y el $7 \%$ ), con las excepciones del nivel III-2, que no tiene buriles, y el IV-4, el nivel inferior, que presenta una proporción bastante alta en relación a los otros niveles $(16,21 \%)$.

La combinación de los porcentajes de raspadores y buriles, es decir, la relación entre IG e IB, queda como sigue. El único nivel en que el IB es superior al IG es el inferior de la estratigrafía, el IV-4. En el resto de niveles el IG es superior al IB, pero entre ellos destaca el nivel IV-3, 

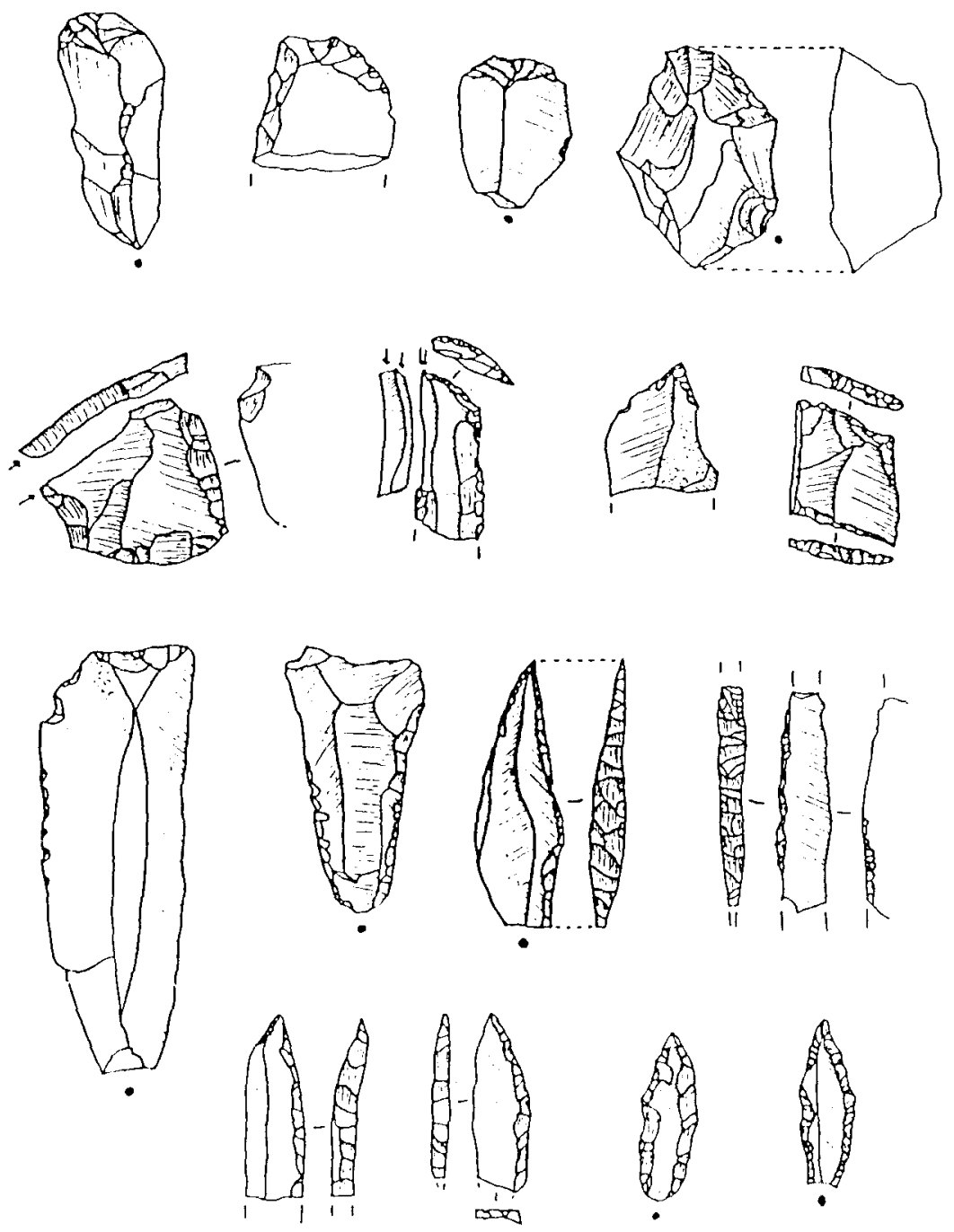

d)

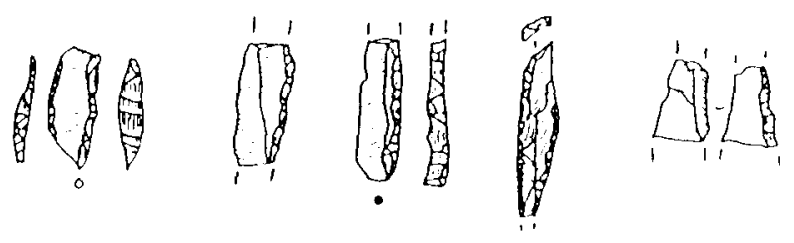

NIVEL $\| / /-1$. 
inmediatamente superior al anterior, en el que los raspadores son sólo ligeramente superiores a los buriles. En el resto, el Bloque III y los niveles IV-1 y IV-2, el predominio del IG sobre el IB es muy neto y amplio.

Dentro de los raspadores resulta también significativa la asociación de raspadores circulares y unguiformes, que se suelen considerar como indicativos del Aziliense. Al considerarlos conjuntamente se descubre una tendencia en la secuencia estratigrágica más significativa que, aunque débil cuantitativamente, hay que valorarla en relación con las elevadas proporciones de la industria sobre laminillas. No existen en los dos niveles inferiores del Bloque IV. Los niveles IV-2, IV-1 y III-4 presentan unas proporciones muy bajas (no superior al $2 \%$ de todos los útiles y entre $5 \%$ y $10 \%$ del indice restringido). En cambio, a partir del III-3 (3,32\% y $17,74 \%$ del indice restringido) la proporción va ascendiendo muy ligeramente hasta el nivel III-1, en donde alcanza la máxima $(4,32 \%$ y $26 \%$ en el índice restringido).

Sólo hay que terminar, respecto a los raspadores, con una consideración que, por la falta en este trabajo de una recogida completa de las medidas de las piezas, es fundamentalmente intuitiva. Ésta es que, a pesar de que los tipos más numerosos no varian a lo largo de la estratigrafía predominando los tipos "Simple y Sobre lasca", sí parece que la longitud es menor en los niveles altos de la estratigrafía. El Bloque III presenta en conjunto un tamaño medio inferior a los del Bloque IV. Esto se debe a que las láminas o las lascas están afectadas por roturas más cerca del frente que los niveles inferiores, especialmente en el IV-3 y el IV-4. Esto sería intrascendente si fueran producto de la casualidad o de las mayores vicisitudes de las piezas de los niveles altos de la secuencia, pero no hay que dejar de lado la posibilidad de la utilización de la rotura dentro de los "gestos" de fabricación de los útiles, como se ha demostrado en Pincevent y Les Etiolles (Leroi-Gourhan, 1983, y Pigeot, 1987), y como parece sugerir la presencia en La Pila de algunos raspadores en los que el retoque del frente interesa parte de la fractura de la lámina.

Llama la atención también el indice específico de las láminas magdalenienses (ILA), es decir, de las piezas con retoque oblicuo escamoso normalmente apuntadas. Aunque presenta unos porcentajes bajos, el más alto es el del nivel IV-1 con 2,15\%, es significativo por la falta casi total en el Bloque III (sólo aparece un único ejemplar dudoso en el nivel superior) de este tipo. Sólo se constatan en el Bloque IV, especialmente en los dos niveles superiores (IV-1 y IV-2). Es de señalar que este tipo ha sido definido en Francia como manifestación típica del Magdaleniense Superior, siendo utilizada incluso como "fósil-guía", lo que supone un cierto criterio cronológico en la secuencia de La Pila. 


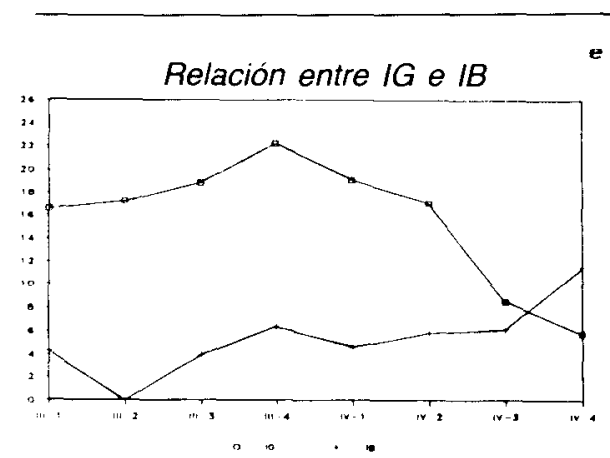

e in

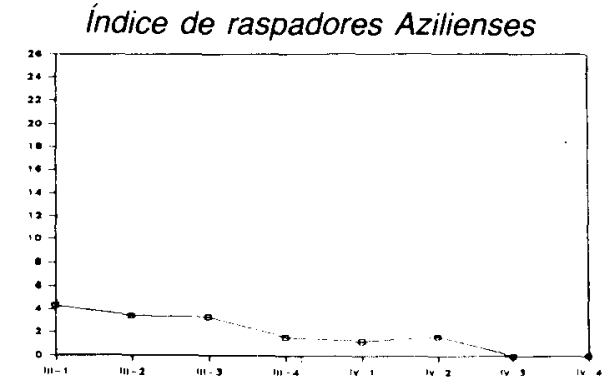

Indice de láminas magdalenienses

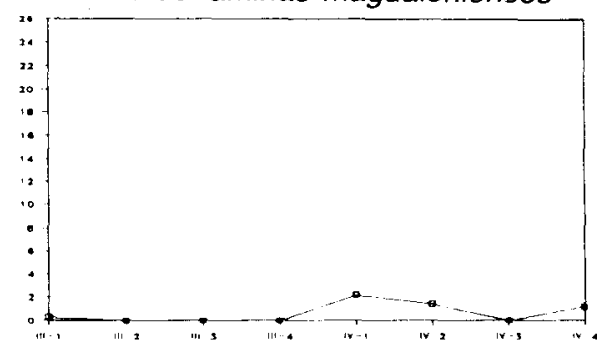

Indice de puntas azilienses

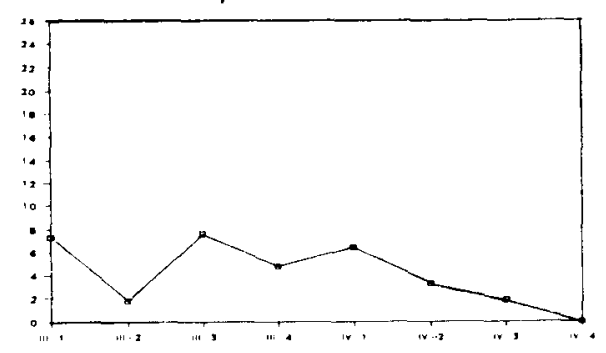

Índice de puntas de dorso

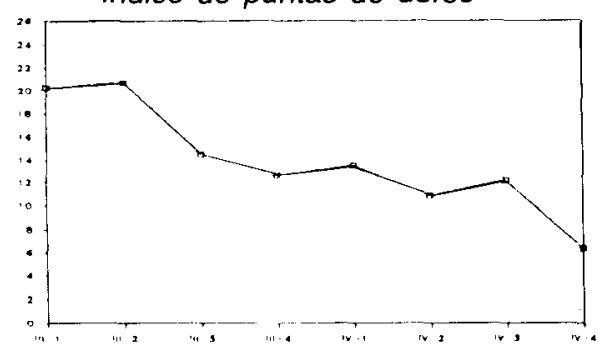

indice de hojitas

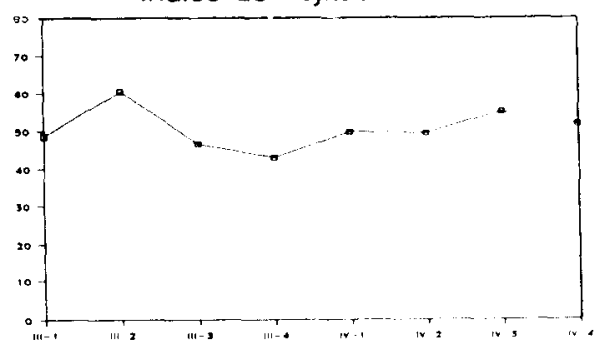

Indice rest. hojas dorso denticuladas
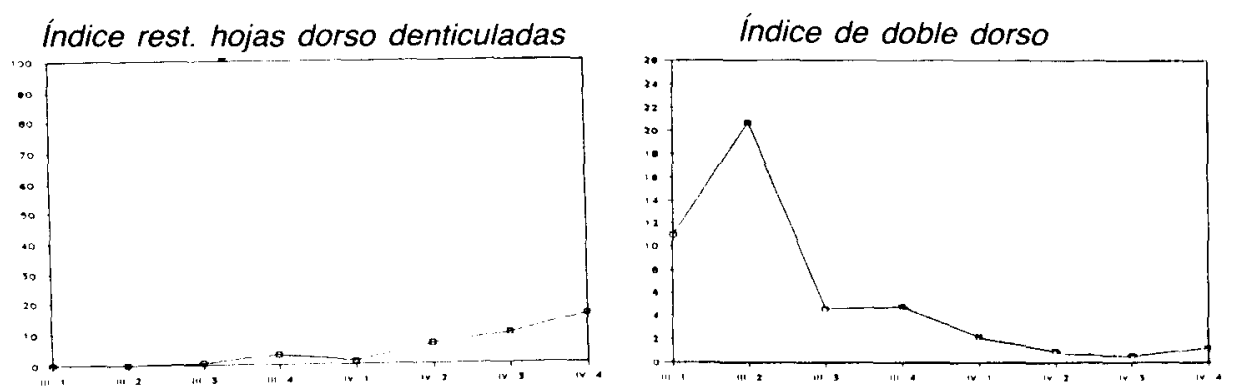

Relación de gráficos de indices más representativos. 
En el índice de las puntas azilienses (IPA) se constata una evolución a lo largo de la secuencia también significativa. En el nivel último, el IV-4, no ha aparecido ninguna de estas puntas, ni siquiera con la utilización amplia de la tipología de Celérier. En el nivel siguiente (IV-3) aparecen en una proporción reducida $(1,83 \%)$, aumentando progresivamente hasta el nivel IV-1; y en el Bloque III se mantiene, con los baches de los niveles III-4 y III-2, presentando el valor máximo de 7,55\%.

Aparte de esto, hemos considerado el índice de puntas de dorso (IPD), en el que hemos incluido las "gravettes", las "microgravettes", las puntas azilienses y las hojitas de dorso apuntadas (tipos núm. 84 y núm. 89 de la lista de Burdeos). La tendencia de este índice es bastante significativa. El nivel con porcentaje más bajo es el inferior de la estratigrafía, en el IV-4, con sólo un 6,36\%. El resto de los niveles del Bloque IV y los dos más inferiores del Bloque III se encuentran en una horquilla entre el $10 \%$ y el $15 \%$. Los dos superiores suponen a su vez un salto hacia arriba de los porcentajes, ambos ligeramente superiores al $20 \%$.

La industria sobre laminillas presenta un indice (lh) muy alto en sus proporciones, estando siempre por encima del $48 \%$, y teniendo el máximo en el nivel III-2, con $60,34 \%$. Respecto a la posible tendencia es la misma que se entrevé en el GP. Los niveles con mayor proporción, sin contar el atípico nivel III-2, son los dos inferiores de la secuencia estratigráfica, siguiéndoles los otros dos niveles del Bloque IV.

Las hojitas de dorso denticuladas (Ihddr) también presentan unas débiles proporciones pero significativas. En el nivel IV-4 se da la mayor proporción del índice restringido $(15,73 \%)$. A partir de éste comienza a disminuir rápidamente hasta reducirse a un $1,10 \%$ en el IV-1, recuperándose ligerísimamente en el III-4, para desaparecer en los niveles superiores del bloque con conchero, III-2 y III-1.

Queda por resaltar un índice realizado aunando todas las piezas que están afectadas por dos dorsos, tanto totales como parciales, en los dos bordes, que apuntan o no la pieza, que hemos denominado «Índice de doble dorso" (IDD). Los tipos que presentan esta particularidad son las "Hojitas de dorso" (apuntadas, fragmentos, enteras y dardos) y las "Hojitas de dorso truncadas". Se han excluido las piezas clasificadas como puntas azilienses. Este índice ha presentado una evolución bastante significativa. En los niveles del Bloque IV, la presencia es casi testimonial, siendo el porcentaje mayor el del nivel IV-4 (3,50\%). En los niveles inferiores del Bloque III el aumento es muy reducido $(4,76 \%$ y $4,53 \%$ en los niveles III-4 y III-3). Pero el gran salto se da en los niveles supe- 
riores, con una altísima proporción en el $111-2(20,69 \%)$, seguramente afectada por la escasez de útiles, y una alta en el III-1 (10,96\%).

\section{PERIODIZACIÓN INTERNA}

Con los datos de las tendencias marcadas por los índices se puede realizar una primera aproximación a la periodización y cronología relativa de los niveles del yacimiento, así como sus rasgos distintivos.

En primer lugar destaca como hecho más reseñable la homogeneidad general de toda la industria lítica del yacimiento, especialmente remarcable al enmarcarse en unos estratos pertenecientes al Paleolítico Superior Reciente, en los que, según consta en la literatura científica reciente, no destaca ningún útil lítico característico.

Pero quizá constatar solamente eso supone abandonar unas evidencias, que aunque pudieran ser excesivamente valoradas en algunos casos al tratarse de diferencias porcentuales pequeñas, permiten, a nuestro juicio, señalar una tendencia evolutiva clara desde el fondo de la secuencia estratigráfica hasta el nivel intacto más reciente.

Llegado a este punto, resulta importante señalar en este momento, lo que se reafirmará más adelante, que las tendencias constatables en la secuencia estratigráfica de la cueva de La Pila, salvo aquellas generales constatadas por los investigadores en otros yacimientos del Cantábrico, sólo configuran una evolución interna, sin que ello signifique que se pretenda generalizar en una evolución del Paleolítico Superior Reciente en ningún ámbito geográfico, cronológico, cultural o económico. Tamaña osadia sería imperdonable en una región como la Cantábrica, en la que se produce una notable variación regional.

Por tanto, la secuencia del yacimiento, en su aspecto tipológico, es muy homogénea y presenta una evolución continua, sin rupturas tipológicas fuertes, pero dentro de ella se pueden distinguir internamente varios conjuntos:

Niveles inferiores del Bloque IV (Niveles IV-4 y IV-3)

El nivel que más se diferencia del resto del conjunto es el nivel inferior, el IV-4, que parece responder a unas tradiciones anteriores al 
conjunto de la secuencia. El nivel superior a éste (IV-3) presenta elementos comunes pero a la vez se acerca más en otras características al nivel siguiente (IV-2).

Como características básicas de este agrupamiento destacan:

- Un porcentaje bajo de raspadores en ambos casos, entre los que no aparecen ni circulares ni unguiformes.

- Un porcentaje alto de buriles en el nivel IV-4, prototipo del agrupamiento, mientras que en el IV-3, nivel de transición, el porcentaje es bajo. En ambos casos predominan los buriles diedros.

- En el primer nivel supera el porcentaje de buriles al de raspadores; en el IV-3, en cambio, el de raspadores es superior al de buriles pero por muy poca proporción.

- Las piezas con retoque simple presentan en los dos niveles un porcentaje alto (por encima del $10 \%$ ), estando presentes sólo de modo testimonial las llamadas «láminas magdalenienses". Las piezas del "sustrato" también se encuentran en una frecuencia alta, asimismo por encima del $10 \%$.

- La proporción de las puntas de dorso («microgravettes», puntas azilienses, hojitas de dorso apuntadas y "dardos") es baja, por debajo del $10 \%$, en el nivel IV-4, mientras que en el de transición aumenta de forma significativa. De entre ellas no se constata, salvo de forma muy reducida en el IV-3, la presencia de puntas azilienses.

- Las hojitas de dorso denticuladas presentan una alta proporción, especialmente en el nivel IV-4, reduciéndose, aunque manteniendo un procentaje alto, en el IV-3.

- Por último, es significativo la proporción muy baja de dobles dorsos y los procentajes muy bajos de hojitas de dorso truncadas.

Niveles superiores del Bloque IV (IV-1 y IV-2)

Este agrupamiento de niveles es el que agrupa al mayor número de útiles. Constituyen un grupo bastante homogéneo internamente, sin presentar, por ejemplo, "niveles de transición". Más bien, si no fuera por su mayor número de piezas, podrían ser considerados estos dos niveles como transitorios entre una caracterización lítica anterior, representada por el nivel IV-4, y los niveles del Bloque III, que parecen responder a otra caracterización posterior. 
Se puede definir por los siguientes comportamientos de la industria lítica.

- Presenta una proporción alta de raspadores, entre los que aparecen de modo muy ligero los raspadores unguiformes y circulares.

- En cambio, la proporción de buriles se presenta muy baja, manteniéndose los diedros mayoritariamente.

- La relación entre buriles y raspadores está, por tanto, claramente inclinada hacia los raspadores.

- Las piezas de retoque simple presentan una proporción baja, así como las piezas del "sustrato", todas ellas por debajo del $10 \%$. En cambio, y a pesar de la débil proporción de piezas de retorque simple, las "láminas magdalenienses" están presentes con unos porcentajes significativos.

- Las puntas de dorso presentan una proporción alta (por encima del $10 \%$ ), entre las que de modo testimonial en el nivel inferior de la secuencia y con un porcentaje bajo en el superior aparecen las puntas azilienses.

- Asimismo, los procentajes de hojitas de dorso denticuladas son muy bajas; junto a éstas, las piezas de doble dorso sólo aparecen testimonialmente.

Niveles del Bloque III (III-1 a III-4)

El agrupamiento de todos los niveles del bloque con cochero se ha debido a que responden a unas características comunes en general. Aunque existen algunas diferencias entre los dos niveles superiores y los inferiores, la presencia muy baja de útiles en los niveles III-2 y III-4 Ileva a tener mucha cautela a la hora de agruparlos.

De todos modos, aunque los consideramos un mismo bloque, parecen separarse netamente los niveles superiores, especialmente el III-1, de los dos inferiores, que ejercen un cierto papel de transición respecto a los dos primeros niveles del Bloque IV, por lo que podría hablarse de dos "subconjuntos".

Las características definitorias son las siguientes: 
MANUEL ÁNGEL LAGÜERA GARCIAA

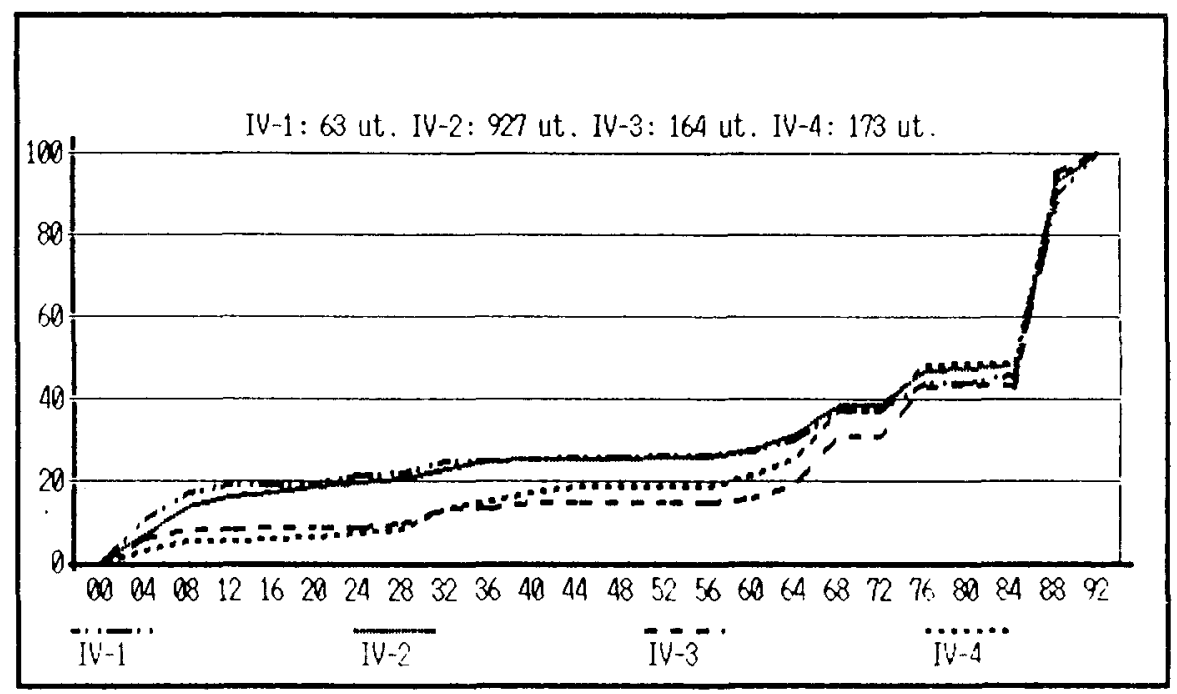

Gráficas acumulativas de los niveles magdalenienses de La Pila.

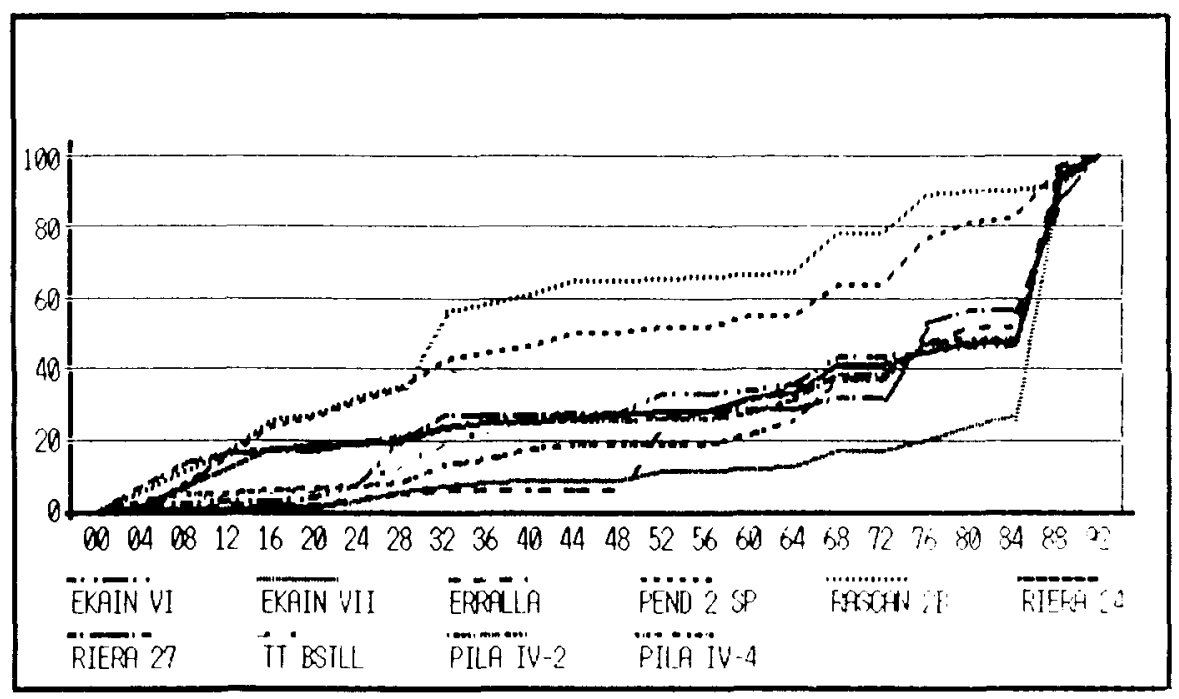

Comparación con otros niveles magdalenienses. 
La tipología del utillaje lítico del yacimiento de La Pila

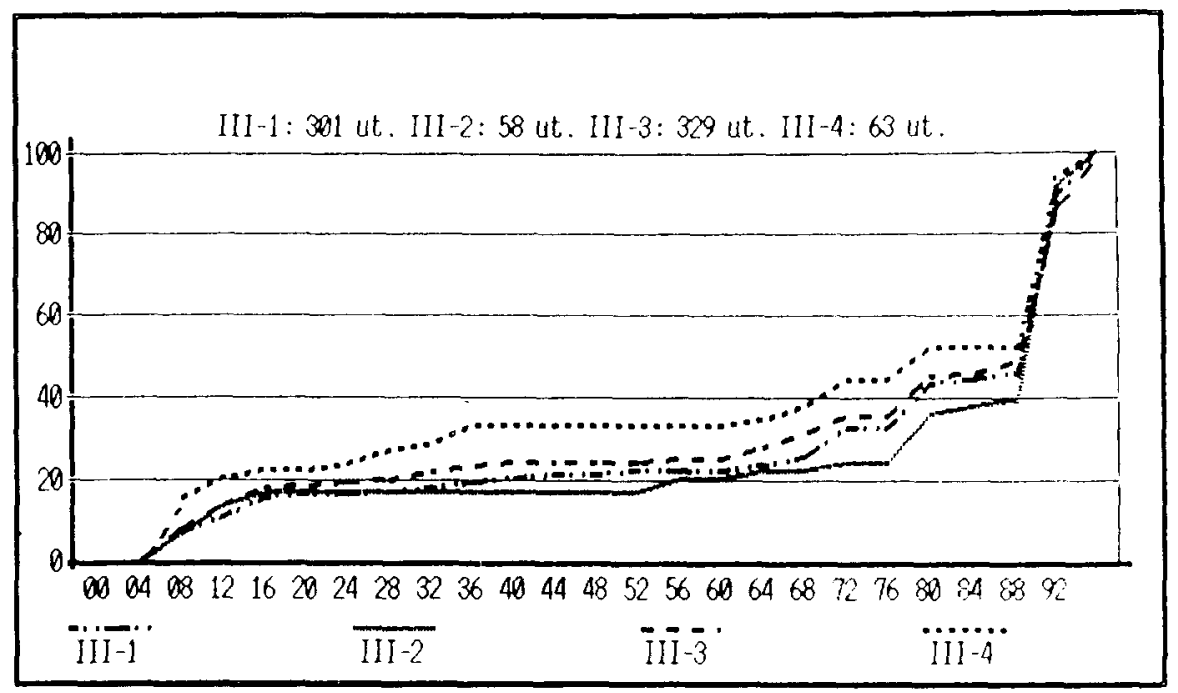

Gráficas acumulativas de los niveles azilienses de La Pila.

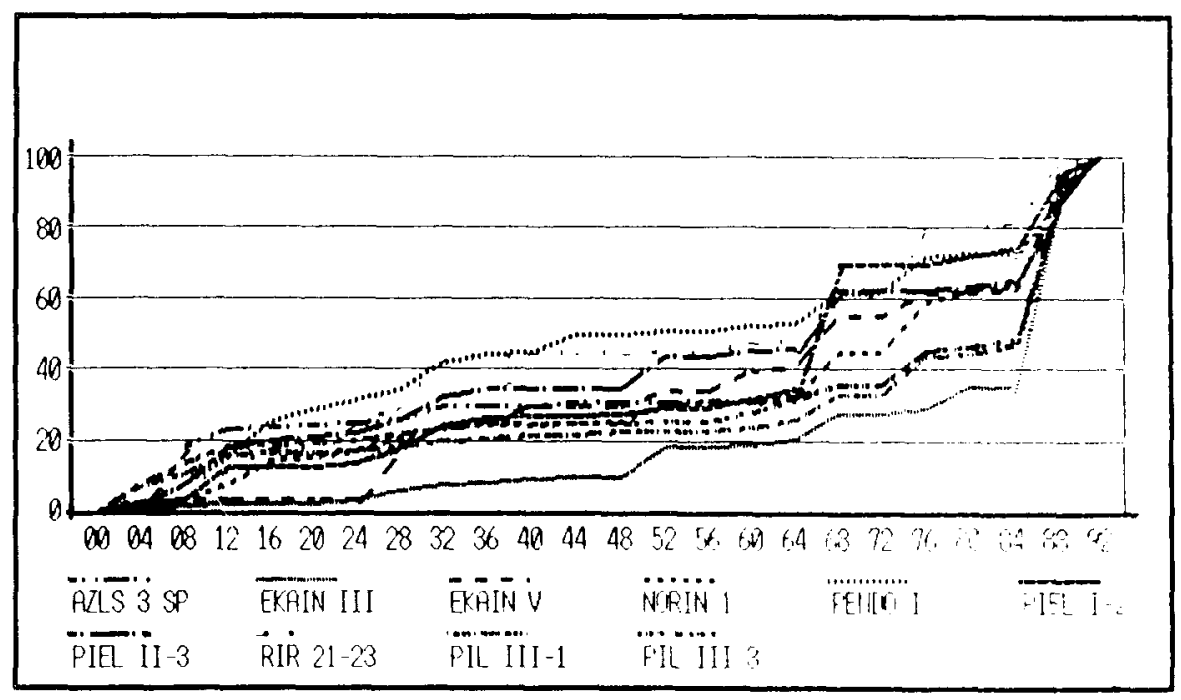

Comparación con otros niveles azilienses. 
- La proporción de raspadores es alta e incluso muy alta en el nivel III-4. Entre ellos destaca el aumento de la proporción de raspadores y unguiformes, salvo el nivel III-4.

- Los buriles son muy escasos, incluso faltan en el nivel III-2. Siguen predominando los buriles diedros.

- La relación de raspadores y buriles está netamente a favor de los primeros.

- Las piezas con retoque simple están presentes en una proporción muy baja, y las láminas magdalenienses son inexistentes. Las piezas del "Sustrato" están en porcentajes bajos en los dos niveles inferiores, pero aumentan por encima del $10 \%$ en los dos niveles superiores.

- Es significativo el aumento considerable de la proporción de las puntas de dorso, especialmente en los niveles III-1 y III-2, mientras que los niveles inferiores mantienen parecido porcentaje al grupo anterior. Entre las puntas destaca la presencia amplia de puntas azilienses, especialmente en el nivel más reciente.

- Igual de significativo es el porcentaje de piezas de doble dorso, que toman unos porcentajes bajos en los niveles inferiores y muy altos en los superiores.

- La proporción de hojitas de dorso trucadas es la más alta de toda la secuencia, presentando, a pesar de algunas irregularidades, su máximo en el nivel III-1.

- En cambio, las hojitas del dorso denticulado desaparecen por completo en los dos niveles superiores, estando presente en proporciones muy bajas en los dos inferiores.

\section{VALORACIÓN CRONOLÓGICA}

Para la valoración cronológica correcta parece necesario, debido a la gran homogeneidad de fondo que se da en el conjunto lítico, prestar atención a los datos de industria ósea y de arte mobilar que se han obtenido de la secuencia de La Pila, así como las, en las fechas de la redacción de este trabajo, escasas dataciones por C14.

Empezando por estas últimas, las fechaciones de las que se tienen constancia por gentileza de Federico Bernaldo de Quirós y Carmen Gutiérrez Saez son: 

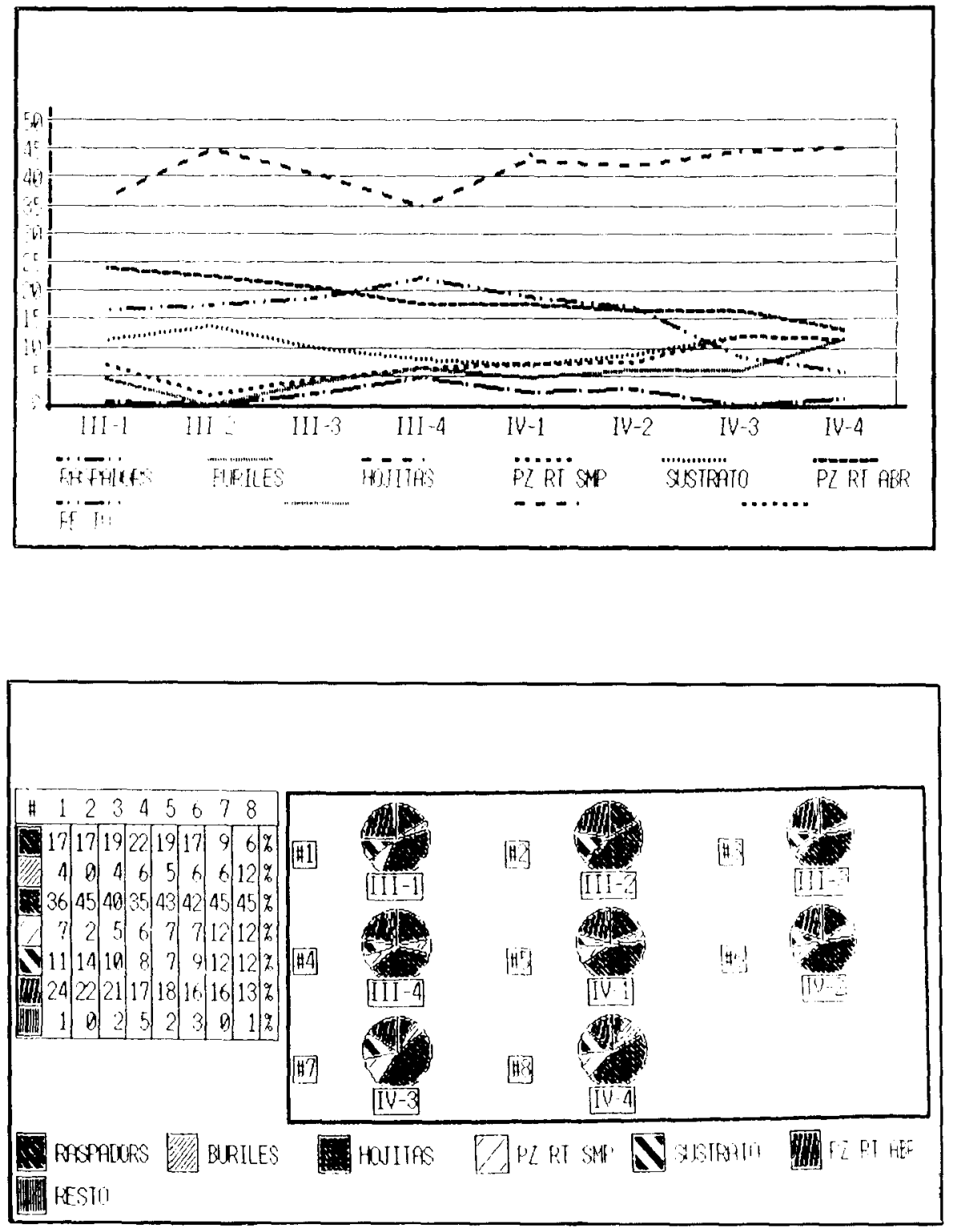

Comparación por grupos tipológicos de los niveles de La Pila. 


$\begin{array}{lll}\text { Nivel III-3 } & \text { GIF } 8040 & 11.710 \pm 120 \mathrm{BP} \\ \text { Nivel IV-2 } & \text { GIF } 8047 & 12.160 \pm 130 \mathrm{BP}\end{array}$

Los datos de la industria ósea y el arte mobiliar, resumidos, se han obtenido del trabajo de Bernaldo de Quirós y otros (en prensa), y son los siguientes:

En toda la secuencia han aparecido 21 arpones, siete de ellos planos. La distribución estratigráfica señala que la totalidad de los arpones circulares se encuentran (salvo dos arpones decorados del nivel III-4b) en el Bloque IV, en concreto, entre los niveles IV-4 y IV-2 (el único arpón circular de doble hilera de dientes ha aparecido en el nivel IV-2); y que los planos, a excepción de uno (sic) de utypologie étrange" del IV-1 y otro con perforación central circular y protuberancia basal del IV-2, se encuentran en el Bloque III.

El número de azagayas de toda la estratigrafía es de 52 piezas, de las que sólo se han encontrado tres fragmentos, elípticos y subtriangulares, en el Bloque III. El resto (salvo una de grandes dimensiones del nivel III-4b) han aparecido en el Bloque IV predominando los tipos subrectangulares y subcirculares.

El resto de la industria ósea está compuesta por un buen número de punzones, distribuidos tanto en un bloque como en otro; también un buen número de colgantes realizados en caninos atrofiados de ciervo, de los que sólo uno se ha encontrado en el Bloque III, y trece agujas y tres "núcleos de agujas", puntas de grandes dimensiones, algunas varillas, tensores, una espátula y una "azuela" (según la interpretación de González Sainz, C., 1989), en su totalidad en el Bloque IV.

En relación con el arte mobiliar hay que señalar que se concentra prácticamente en su totalidad en el Bloque IV. Destacan las representaciones figurativas: un caballo grabado en un fragmento de hueso coxal de nivel IV-3, tres serpentiformes sobre arpones de los niveles III-4b (dos) y IV-3 (uno), así como la parte posterior de un pez en una azagaya del nivel IV-1. Además de estas representaciones se encuentra una amplia decoración no figurativa que muestran (sic) "que l'ensemble des sagaies décorées ( $y$ asimismo arpones decorados) du Magdalenien de La Pila fait preuve d'une grande homogénéitè".

Además de la documentación suministrada por la industria ósea y las fechaciones de radiocarbono conviene tener en cuenta la evolución que, en líneas generales, han desarrollado los autores sobre las características de la industria, lítica en particular, para el Magdaleniense y el Aziliense. 
Con todos estos datos es posible realizar una valoración cronológica de las agrupaciones de niveles realizados por nosotros.

En primer lugar, el Bloque IV, recordamos que es el que estratigráficamente es inferior a la acumulación de conchero y el que presenta la totalidad del arte mueble.

En realidad, el III-4b si contiene dos arpones decorados con serpientes, pero si se confirma la génesis sedimentológica de este nivel como producto de una colada de barro intrusiva y fuertemente erosiva, es bastante factible que la industria, tanto lítica como ósea, que se engloba en este nivel pertenecería a los niveles inferiores (Bloque IV).

Los arpones presentes en este nivel son mayoritariamente (salvo dos) de sección circular, y el resto de industria ósea es bastante variada.

En cuanto a la datación existente para uno de estos niveles (12.160 \pm 130$)$ se encuadra perfectamente dentro de una batería de fechas recogidas en la región cantábrica para los niveles datados como Magdaleniense Superior-Final. En realidad se encuentra entre las fechas más recientes recogidas y consideradas coherentes para este período, en paralelo a la fechación del nivel 23 de La Riera, Magdaleniense Superior $(12.620 \pm 300)$, del nivel VI, Magdaleniense Final, de Ekain (12.050 \pm $190)$, del nivel III de Erralla, Magdaleniense Final (12.310 \pm 190$)$ o del nivel 2, Magdaleniense Superior, de Rascaño (12.282 \pm 164$)$.

Además, como se ha visto, la industria lítica presenta en los niveles inferiores un porcentaje superior de buriles que de raspadores, el predominio entre estos últimos de los tipos simples y sobre lasca, la presencia alta de hojitas retocadas, la presencia reducida de puntas de dorso y la inexistencia de puntas azilienses y de doble dorso. Para que progresivamente se vaya produciendo la reducción de buriles en relación a los raspadores, el mantenimiento de las hojitas, la presencia de tipos especiales como los raspadores circulares, unguiformes y puntas azilienses, así como el aumento de las puntas de dorso, y, quizá, una reducción de las medidas de los raspadores.

Con estos datos resulta sumamente fácil situar estos niveles en el periodo denominado últimamente Magdaleniense Superior-Final. Pero es interesante plantearse la posibilidad de división entre el Magdaleniense Superior y el Final, lo que se realiza explícita o implícitamente por todos los autores.

Superada, al menos parcialmente, la división de Obermaier basada en el número de hileras de dientes de los arpones, se señaló por parte de los autores las grandes dificultades de distinguir entre unas fases y 
otras taxativamente (evidente triunfo de los "fósiles-guía" sobre la renovada tipología estadística).

El Grupo de Trabajo de Prehistoria del Cantábrico (1977) señalaba, con mucha prudencia, como posible "fósil-guía" los arpones con perforación para el Magdaleniense Final. La industria lítica, que responde al proceso conjunto de microlitización por la reducción de los tamaños y por aumento de hojitas, se caracterizaba en el Magdaleniense Superior por la alternancia variable según el yacimiento de buriles o raspadores; el Magdaleniense Final, por la presencia de raspadores cortos, puntas azilienses y "microgravettes", y el Aziliense, por la presencia (mayor) de raspadores unguiformes, circulares y puntas azilienses en Occidente y «microgravettes» en Oriente.

Más coherente es la interpretación de González Sainz (1989) pero que a la hora de señalar la posibilidad de distinguir entre estos dos períodos entra en una ambigüedad calculada. Por un lado define en la evolución interna del período que va del Magdaleniense Medio al Aziliense por "tendencias", práctica que resulta más correcta que el establecimiento de "facies" por ejemplo; pero, por otro, lanza otras ideas que parecen permitir una periodización de este período, como es el caso de resucitar parcialmente las tesis de Obermaier sobre las hileras de dientes al señalar la presencia tardía en las estratigrafías magdalenienses del Cantábrico del arpón de dos hileras.

De las «tendencias" que describe se extraen en la industria ósea la mayor abundancia de arpones con perforación en las fases finales del Magdaleniense, así como los arpones con protuberancias. En la industria lítica corrige la idea imperante de un aumento de la industria microlaminar con el comienzo del período, al constatar la presencia alta de hojitas en los niveles del Magdaleniense Medio, situando el aumento de laminillas en las fases finales del período. Además marca el progresivo aumento de los tipos cortos en los raspadores, la reducción de los buriles (independientemente de que sean superiores o no a los raspadores) - corrigiendo a Fernández-Tresguerres (1980) que consideraba que este cambio se produce en el Aziliense-, el aumento en un principio del índice laminar para su reducción posterior...

Es reseñable que la ambigüedad, a la que anteriormente nos hemos referido, responde, al estudiar todos los yacimientos de la región cantábrica, a un condicionante fundamental que es la variedad de materias primas. La adaptación de unos pueblos con una misma tradición cultural a las características de la materia prima (diferenciada geográficamente: peor calidad y escasez en el Oeste y mayor calidad y abundancia en el 
Este) impide valorar taxativamente las diferencias tipológicas como producto de diferencias cronológicas, "culturales", e incluso funcionales, o al menos no categóricamente.

Pero en el caso del yacimiento de La Pila puede eludirse el condicionamiento de la materia prima, ya que tuvo que ser, salvo muy difíciles excepciones (como el "descubrimiento" de una nueva fuente de materia prima, por ejemplo), la misma en toda la secuencia estratigráfica, ya que al abarcar sólo desde el Magdaleniense Superior-Final al Aziliense debió crearse la estratigrafía en un período de tiempo «relativamente» corto. Por lo tanto, sí es posible aventurar el distingo entre Magdaleniense Superior y Final.

El Magdaleniense Superior abarcaria los dos niveles inferiores. Más claramente el IV-4, ya que el IV-3 presenta ya elementos de transición como se ha comentado en capítulos anteriores.

Estaría definido por presentar, a pesar de su poca importancia en volumen de sedimento, la mayor parte del arte figurativo (salvo los dos arpones con serpientes del nivel III-4b que bien pudieran haber pertenecido a estos niveles antes de ser arrasados parcialmente por la colada de barro en la que están integrados), es decir, el caballo grabado sobre un fragmento de hueso de cadera, la espátula decorada y un arpón decorado con otra serpiente.

La industria ósea se definiría por la presencia de abundantes azagayas y de arpones de sólo una hilera de dientes, entre los que ya aparecen arpones con perforación.

La industria lítica del Magdaleniense Superior está conformada por un porcentaje reducido de raspadores, mayoritariamente "simples y sobre lasca", con una proporción menor o ligeramente superior a la relativamente alta de buriles, estos últimos dominados por los diedros. La industria microlaminar es muy abundante, de la que, aunque dominan mayoritariamente de "hojitas de dorso", destaca la presencia en un porcentaje alto las "hojitas de dorso denticuladas" y la inexistencia de piezas de "doble dorso". Además se haya un porcentaje alto de piezas esquirladas $y$ de piezas con retoque oblicuo, mayoritariamente simple.

El Magdaleniense Final abarcaria los dos niveles superiores del Bloque IV, el IV-1 y el IV-2, presentando ambos elementos claramente magdalenienses y otros definidos como azilienses.

La datación por radiocarbono que se tiene para el Magdaleniense, precisamente en el IV-2, se sitúa, como ya hemos visto, entre las más recientes de la bateria de fechas aceptadas como correctas en los últi- 
mos periodos del Magdaleniense, lo que corroboraría la periodización relativa.

El arte mueble estaría definido por una presencia muy escasa de arte figurativo, a pesar del gran volumen de sedimentos y de hallazgos óseos y líticos que presentan, especialmente el IV-2. Sólo podria hablarse de la azagaya decorada con una cola de pez.

La industria ósea presentaria su máxima expresión con una presencia muy amplia de todos los tipos, especialmente azagayas, agujas y colgantes sobre caninos de ciervo atrofiados, pero sólo en el IV-2, reduciéndose enormemente en el IV-1. Los arpones son mayoritariamente de una hilera de dientes, pero destaca la presencia de uno de dos hileras, lo que serviria de apoyatura para esta periodización, ya que González Sainz considera que aparecen en las fases tardías, y la de dos arpones planos, uno de "factura" aziliense pero con perforación circular (en el IV-1) y otro de doble hilera de dientes y de (sic) "tipología extraña" (en el (V-1), lo que implica claramente un carácter tardio para dichos niveles.

La industria lítica, como se ha señalado de forma exhaustiva, estaría definida por un dominio amplio de los raspadores, entre los que aparecen los unguiformes y los circulares, sobre los buriles. La industria microlaminar se mantiene muy alta, apareciendo con porcentajes relativamente altos los de "doble dorso" y las "puntas azilienses".

En este punto es interesante hablar de dos paralelismos trazados por los investigadores: uno, indicado por Fernández-Tresguerres (1980) y González Sainz (1989), es la coincidencia de la alta proporción de buriles con el desarrollo extraordinario de la industria ósea y el arte mueble y, con la desaparición o enrarecimiento de éstos, la reducción amplia de los primeros; y el otro, indicado por González Sainz (1989), la vinculación del aumento de hojitas y puntas de dorso, utilizadas insertadas en un vástago (que se supone de madera) que aumentan considerablemente en la fase final del Magdaleniense Superior-Final con la reducción drástica de la industria ósea. En los dos casos es reseñable que la industria del yacimiento de La Pila no se adapta totalmente a ninguna de ellas.

En el primer caso, Fernández-Tresguerres sitúa la decadencia de la industria ósea y, por tanto, la reducción del porcentaje de buriles en el Aziliense, mientras que González Sainz los sitúa en las fases tardías (¿Magdaleniense Final?) del período de su estudio. Además señala que en el Oriente del Cantábrico, debido a la poca presencia de buriles, el condicionante de la escasez de buena materia prima habría llevado a la utilización de otras piezas para realizar el trabajo que en las zonas de buena materia prima (léase País Vasco) se realizaban con buriles. Esto 
no se adapta a La Pila, que al tratarse de un solo yacimiento neutraliza la "variante» de la materia prima, porque el mayor desarrollo de la industria ósea se manifiesta en el nivel IV-2 en el que los buriles se han reducido ampliamente ya desde el nivel anterior. En todo caso se paraleliza más en este yacimiento con el arte figurativo, ya que se encuentra mayoritariamente en los niveles inferiores donde los buriles alcanzan su mayor representación.

En el segundo caso el «incumplimiento" de La Pila es producto de que el aumento considerable de las hojitas de dorso no se produce ni en las fases finales del Magdaleniense ni en el Aziliense. En toda la secuencia de La Pila la proporción de hojitas es muy alta y, en todo caso, es ligeramente superior en los niveles inferiores (IV-3 y IV-4), lo que implica que sus más altos porcentajes "convivieron" con el mayor desarrollo de la industria ósea y del arte mueble. Otra cuestión es la de las puntas de dorso; éstas son muy pocas en el nivel IV-4, aumentan bastantes en el resto de los niveles magdalenienses (en los que hay una importante industria ósea) y de forma importante con el Aziliense. Esto podría adaptarse a la disminución de la industria ósea, aunque de una forma bastante matizada. De todos modos seria interesante comprobar si hay diferencias tipométricas y de factura entre las hojitas y las puntas de dorso de los niveles inferiores de la secuencia respecto a los superiores, por si éstos hubieran sufrido alguna variación que pudiera tomarse como producto de una variación ufuncional» de las hojitas de dorso.

El otro conjunto de niveles es el Bloque III, que como se ha escrito con anterioridad está constituido por un conchero y se sitúa en la zona alta de la secuencia estratigráfica. La información existente abarca la industria lítica, evidentemente, la industria ósea y una fechación de radiocarbono.

El arte mobiliar no está presente en ninguno de los niveles de este bloque, y en la industria ósea destacan los arpones planos que salvo uno son de una hilera de dientes.

La datación existente $(11.710 \pm 120)$, aunque es coherente por el momento estratigráficamente, es una fecha demasiado antigua para datar niveles con arpones planos. En realidad sólo coincide con la fecha azi-

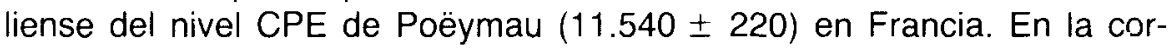
nisa cantábrica, salvo la fecha, contradictoria del resto de la secuencia, del nivel 27 de La Riera (12.760 \pm 400$)$, la única fecha que tiene alguna cercanía es la del nivel $3 e$ de Los Azules (11.190 \pm 350 ).

La industria lítica señala un dominio de los raspadores sobre los buriles, aumentando los raspadores circulares y unguiformes. En la indus- 
tria microlaminar, que se mantiene alta, destaca el aumento de las puntas de dorso, en especial de las puntas azilienses y de los "dobles dorsos".

La literatura científica mantiene una homogeneidad en señalar las características del Aziliense, una vez superado el concepto trasnochado de la "decadencia aziliense". Se señala por todos los autores consultados, especialmente Fernández-Tresguerres (1980), la desaparición del arte mueble figurativo, el enrarecimiento de la industria ósea, en la que aparece como "importación" el arpón plano, y una industria lítica que, en todo caso, presenta un aumento de los «tipos nuevos» aparecidos en la fase final del Magdaleniense.

Es evidente, con estos datos, la pertenencia de los niveles del Bloque III al Aziliense. Las únicas dudas posibles se dan con el nivel III-4 que no contiene ningún arpón y cuya industria lítica en ocasiones, como confirma el cálculo de distancias, se acerca más a los niveles inferiores que al resto del bloque. Pero se incluye en el conjunto porque, aunque presenta una matriz arcillosa más compacta que los niveles superiores y los restos de moluscos enrarecen, en la zona cercana a la boca está separado de los niveles inferiores por la cuña arcillosa en que consiste el nivel III-4b.

El único dato discordante, el de la fecha, que parece a todas luces demasiado antigua en relación con los yacimientos próximos. La coherencia estratigráfica que de momento mantiene tiene que confirmarse por las dataciones de los niveles por encima, y por debajo. Si aun asi lo mantuviera habría que vérselas con un Aziliense más antiguo que el de los Pirineos y el del sureste francés, situación de la que no tiene ningún dato publicado en la actualidad.

Por último, nos planteamos unas reflexiones sobre el origen del Aziliense, en realidad se habla del arpón aziliense, que se sitúa en los Pirineos, según los autores Fernández-Tresguerres (1980) y González Sainz (1981). La primera dificultad que surge es de tipo teórico, ya que parece difícil de aceptar que se produzca la rápida expansión de un "modelo nuevo" de importación de arpón cuando se abandonan los modelos anteriores, muchos de ellos con adaptaciones regionales como el arpón de perforación, y el resto de los componentes materiales como la industria lítica presentan una homogeneidad importante con los niveles magdalenienses y los cambios entre ellos se produce paulatinamente. A parte de esto llama la atención que las dataciones existentes para el Aziliense cantábrico y el pirenaico son similares por lo que resulta más difícil de aceptar cuando la proliferación de este modelo es sincrónico en una zona y otra. Por último, se tiene en cuenta la no presencia hasta el 
momento de "precedentes", es decir, de arpones en los niveles magdalenienses que sean antecedentes formales de los arpones azilienses. Sin tener muchos conocimientos de tecnología ósea parece factible tomar en La Pila como precedentes, si no el de "tipología extraña" de dos hileras de dientes del nivel IV-1, si, por lo menos, el del nivel IV-2, plano, con mayor tamaño del que habitúan los azilienses propiamente dichos, con una factura de los dientes similar a los azilienses, pero con una perforación circular, en vez de forma de ojal.

\section{EPILOGO}

Es el momento más adecuado para recapitular sobre los datos y las informaciones suministradas anteriormente, teniendo como punto de partida la estratigrafia del yacimiento de La Pila.

En primer lugar, hay que recordar to dicho anterioremente respecto a la improcedencia de dar un carácter general a la interpretación y periodización llevadas a cabo en este yacimiento. Pero parece de justicia senalar, a su vez, la importancia que tiene esta estratigrafía en el estudio de la transición del Magdaleniense al Aziliense en la región cantábrica. Son escasos los yacimientos publicados con datos actuales que respondan a dicho periodo de transición. Practicamente sólo se puede hablar de Ekain para el País Vasco, La Riera para Asturias y La Pila en Cantabria.

Por tanto, este yacimiento cobra importancia debido a que presenta una estratigrafia "física» que puede confirmar o desmentir las conclusiones existentes sobre la transición Magdaleniense-Aziliense realizadas mayoritariamente mediante "estratigrafía comparada".

En cuanto a la industria lítica, en concreto a la tipología, objeto de este trabajo, se han confirmado la mayor parte de las "tendencias" señaladas hasta la actualidad en la literatura cientifica.

El final del Paleolítico Superior, al menos a partir de las primeras fases del Magdaleniense Superior (ya en el Magdaleniense Medio si seguimos a González Sainz), está configurado por la presencia amplísima de industria sobre hojita, especialmente de laminillas de dorso. El muy alto porcentaje de éstas en las excavaciones actuales invalida parcialmente el argumento de la "sobredimensión" de las laminillas por su mayor tendencia a la rotura. Aun dando el carácter de "accidente» a todas 
las roturas de las laminillas, lo que no está confirmado en absoluto, el porcentaje de hojitas "enteras" que pudiera resultar sigue siendo mayoritario entre el conjunto de utillaje. En La Pila, la industria microlaminar domina absolutamente las estadísticas pero no presenta ninguna modificación significativa a lo largo de la secuencia por lo que, en este caso, no pueden vincularse las hojitas al proceso de "azilienización".

El resto del conjunto lítico mantiene las "tendencias" señaladas con anterioridad. Los buriles dominan en el nivel inferior, como ocurre con el Magdaleniense Superior de La Riera (nivel 28), para invertirse la relación respecto a los raspadores en los niveles superiores. Las "láminas magdalenienses", en proporciones muy bajas, se concentran mayoritariamente en el «Magdaleniense Final» de La Pila. Las piezas con retoque oblicuo presentan su mayor porcentaje en los niveles inferiores y las del "Sustrato" se mantienen con oscilaciones en la misma tónica. Los «útiles azilienses" (puntas y raspadores unguiformes y circulares) se presentan en los niveles finales del Magdaleniense, aunque cobran entidad con el Aziliense. Los mismo ocurre con las puntas de dorso en general.

Aparte de estos elementos ya indicados por la literatura científica, hemos encontrado "tendencias" significativas en las hojitas de dorso denticuladas cuya presencia casi exclusiva se encuentra en los niveles del Magdaleniense Superior, las hojitas de dorso truncadas que, a pesar de unos porcentajes muy bajos, tienden a concentrarse en los niveles azilienses y, sobre todo, la presencia de doble dorso en las piezas, cuya presencia más señalada se da en los niveles azilienses más recientes.

Es interesante resaltar que en La Pila, al menos, no se cumplen los binomios presencia de laminillas y disminución de industria ósea, por una parte, y alto porcentaje de buriles y gran desarrollo de la industria ósea, por otra.

La razón aducida en el primer caso es que la utilización de vástagos en los que se introdujeran las hojitas iría sustituyendo los arpones y la industria ósea en general. El salto se produce en el Aziliense o últimos momentos del Magdaleniense. Sin embargo, en La Pila cuando hay mayor desarrollo de la industria ósea es cuando se dan las proporciones más altas de hojitas. Y lo mismo ocurre en Ekain donde, aunque los porcentajes de hojitas son más variables, el máximo (nivel III) y el siguiente corresponden con los niveles de mayor presencia de industria ósea. En La Pila, en todo caso, se daría una relación de la desaparición de la industria ósea con las puntas de dorso.

Algo similar ocurre con los buriles y la industria ósea. Se suele considerar que existe esta relación basándose en el supuesto de la vincula- 
ción del trabajo con buril al trabajo de hueso y asta. Por proporción tampoco se da en La Pila, porque donde hay más presencia de industria osea es precisamente donde se reduce la presencia de buriles. En todo caso porporcionalmente corresponde la mayor presencia de buriles con la mayor presencia de arte mueble.

Respecto a esto, consideramos que la mera "coincidencia" de unas proporciones no suministra razones de "casualidad" entre ellas y, por tanto, es necesario tener otros criterios para llegar a binomios de comportamiento técnico como los anteriores.

Para acabar con las reflexiones sobre los útiles de este yacimiento, nos resulta interesante volver sobre la reutilización de éstos teniendo como referencia la "punta de cara plana» aparecida en el nivel IV-2.

En el período Solutrense, fuera del yacimiento ya que el nivel más antiguo tiene arpones circulares de una hilera de dientes, se realiza, con la técnica depurada que necesita, una buena "punta de cara plana".

El sílex que se utiliza es igual al que se usa en el yacimiento en un periodo Magdaleniense Superior y Final para hacer las láminas y los útiles más perfectos técnicamente y que es muy escaso ya que sólo aparecen productos acabados de talla y no núcleos ni productos de acondicionamiento. Esto parece indicar que es escaso y, por la falta de restos de talla, traído de lejos del yacimiento.

La realización de esta punta supuso un trabajo considerable, que responde a unas necesidades funcionales, pero también a unas tradiciones técnicas, que es 10 mismo que decir a unas tradiciones "culturales".

Ya en el Magdaleniense, esta pieza, realizada sobre un sílex de calidad, es recogida y, a pesar de su "bella factura", se la reconvierte en un buril sencillo, diedro sobre rotura, sin ninguna complicación técnica.

La razón de desechar este útil a pesar de su complicación técnica responde, a nuestro juicio, a criterios "cultural-técnicos". Es sumamente improbable que la "función" para la que se realizó la "punta de cara plana", sea la que sea, no se conservara en el periodo Magdaleniense, y sí, en cambio, que dicha "función" se realizaba con otro "útil nuevo", que responde a una tradición artesanal diferente. $Y$, por tanto, el Magdaleniense que encuentra esa pieza la reconvierte en un útil que responda a las necesidades que se le presentan, pero, a su vez, a los "condicionantes culturales" que como miembro de todo grupo le afectan de modo determinante. Esto supone desechar la utilidad de una pieza realizada con un cuidadoso retoque plano. 
Por último, en relación a la «transición» del Magdaleniense al Aziliense a que responde el yacimiento de La Pila hacemos la siguiente reflexión, arriesgada por falta de dataciones y de las conclusiones definitivas de la sedimentología, y sin hacer un estudio profundo del resto de yacimientos en los que se dan características similares.

Como ya se ha indicado, en el artículo de Bernaldo de Quirós y otros (en prensa) los diferentes elementos que se consideraban como definitorios del Aziliense o, al menos, del Final del Magdaleniense (desaparición del arte mueble y de mucha industria ósea, sustitución del modelo de arpón, aparición de puntas y "raspadores azilienses...») presentan un comportamiento "independiente" entre ellos, es decir, los cambios no se producen simultáneamente.

Por un lado, en la industria lítica, el dominio de los raspadores sobre los buriles comienza en el inicio de la estratigrafía (nivel IV-3). Lo mismo ocurre con la aparición de las "puntas azilienses". Los raspadores unguiformes y circulares toman proporciones altas una vez pasado el nivel III-4, ya en el Aziliense, aunque su presencia es anterior. Los dobles dorsos presentan su mayor desarrollo en los dos niveles superiores de la estratigrafía.

Por otro lado, en la industria ósea y el arte mueble se producen los siguientes cambios. El arte mueble disminuye mucho después del nivel IV-3, desapareciendo en el Aziliense. Los arpones circulares también desaparecen en el Aziliense, mientras que las azagayas, aunque se reducen enormemente, se mantiene en este periodo. Los arpones planos aparecen ya en el Magdaleniense (arpón plano con perforación circular del nivel IV-2).

Con todo este conjunto de datos, parece más efectivo considerar todos estos cambios como producto de una articulación progresiva y sin censuras que llevó a la sustitución de unos modelos de comportamiento económico, social, cultural, etc., por otros, sin que sea necesaria la «importación" de todos o alguno de los elementos del Aziliense para que éste se desarrolle en plenitud.

Es decir, nos parece más factible que el Aziliense, a la vista de los datos de La Pila, en todo su componente material, sea producto de una evolución interna $y$, en concreto, el arpón aziliense no tenga porqué responder a modelos extraños, aún más cuando parece que el arpón del nivel IV-2 responde a un modelo intermedio entre los arpones circulares y los planos. 
Ya no entramos, por falta de datos, en la cuestión de si surgió de la Península lbérica el modelo de arpón plano, si fue producto de una convergencia de diversas culturas, o, quizá lo más posible, que fuera producto de un "caldo de cultivo" general, que no puede encerrarse en una zona geográfica determinada. 


\section{Anexo 1}

Útiles de La Pila según la lista-tipo de Sonneville-Bordes/Perrot

\begin{tabular}{|c|c|c|c|c|c|c|c|c|}
\hline LPS & III-1 & $111-2$ & III-3 & $111-4$ & $\mathrm{IV}-1$ & IV-2 & IV-3 & IV -4 \\
\hline 01 & 19 & 3 & 24 & 10 & 30 & 51 & 7 & 3 \\
\hline 02 & 3 & 0 & 3 & 0 & 1 & 6 & 1 & 1 \\
\hline 03 & 0 & 1 & 0 & 0 & 3 & 7 & 1 & 1 \\
\hline 05 & 3 & 0 & 2 & 0 & 5 & 12 & 2 & 0 \\
\hline 06 & 0 & 0 & 0 & 0 & 0 & 0 & 0 & 0 \\
\hline 07 & 0 & 0 & 0 & 0 & 0 & 1 & 0 & 0 \\
\hline 08 & 8 & 4 & 17 & 3 & 17 & 53 & 2 & 4 \\
\hline 09 & 4 & 2 & 7 & 1 & 3 & 12 & 0 & 0 \\
\hline 10 & 9 & 0 & 4 & 0 & 1 & 3 & 0 & 0 \\
\hline 11 & 1 & 0 & 1 & 0 & 2 & 3 & 0 & 0 \\
\hline 12 & 1 & 0 & 2 & 0 & 0 & 4 & 0 & 0 \\
\hline 14 & 0 & 0 & 0 & 0 & 0 & 2 & 0 & 0 \\
\hline 15 & 2 & 0 & 2 & 0 & 0 & 4 & 1 & 1 \\
\hline 17 & 0 & 0 & 1 & 0 & 0 & 7 & 0 & 0 \\
\hline 18 & 0 & 0 & 1 & 1 & 1 & 5 & 0 & 1 \\
\hline 19 & 0 & 0 & 0 & 0 & 0 & 1 & 0 & 0 \\
\hline 21 & 0 & 0 & 0 & 1 & 1 & 0 & 0 & 0 \\
\hline 22 & 0 & 0 & 0 & 0 & 0 & 1 & 0 & 0 \\
\hline 23 & 0 & 0 & 1 & 0 & 2 & 2 & 0 & 1 \\
\hline 24 & 2 & 0 & 1 & 1 & 3 & 6 & 0 & 0 \\
\hline 25 & 0 & 0 & 1 & 0 & 0 & 1 & 0 & 0 \\
\hline 26 & 0 & 0 & 1 & 0 & 0 & 0 & 0 & 0 \\
\hline 27 & 2 & 0 & 2 & 0 & 1 & 4 & 1 & 0 \\
\hline 28 & 0 & 0 & 2 & 1 & 1 & 7 & 1 & 2 \\
\hline 29 & 1 & 0 & 2 & 0 & 3 & 6 & 2 & 1 \\
\hline 30 & 4 & 0 & 2 & 3 & 5 & 9 & 2 & 6 \\
\hline 31 & 0 & 0 & 1 & 0 & 1 & 6 & 2 & 2 \\
\hline 34 & 0 & 0 & 0 & 0 & 1 & 1 & 0 & 0 \\
\hline 35 & 1 & 0 & 1 & 0 & 0 & 11 & 0 & 1 \\
\hline 36 & 2 & 0 & 3 & 0 & 0 & 5 & 0 & 0 \\
\hline 37 & 2 & 0 & 0 & 0 & 1 & 0 & 0 & 0 \\
\hline 38 & 1 & 0 & 0 & 0 & 0 & 1 & 0 & 3 \\
\hline 39 & 0 & 0 & 0 & 0 & 0 & 0 & 1 & 1 \\
\hline 40 & 0 & 0 & 0 & 0 & 0 & 3 & 1 & 0 \\
\hline 41 & 0 & 0 & 0 & 0 & 1 & 2 & 0 & 2 \\
\hline 44 & 0 & 0 & 0 & 0 & 1 & 0 & 0 & 0 \\
\hline 48 & 2 & 0 & 0 & 0 & 0 & 0 & 0 & 0 \\
\hline 49 & 0 & 0 & 2 & 0 & 0 & 0 & 0 & 0 \\
\hline 51 & 0 & 2 & 1 & 0 & 1 & 4 & 0 & 0 \\
\hline 57 & 1 & 0 & 0 & 0 & 0 & 2 & 1 & 2 \\
\hline
\end{tabular}


La tipologia del utillaje lítico del yacimiento de La Pila

\begin{tabular}{rrrrrrrrr}
\hline LPS & III- & III- & III-3 & III-4 & IV-1 & IV-2 & IV-3 & IV-4 \\
\hline 58 & 1 & 0 & 1 & 0 & 1 & 2 & 0 & 0 \\
59 & 1 & 0 & 3 & 0 & 0 & 1 & 0 & 1 \\
60 & 1 & 1 & 5 & 1 & 2 & 10 & 1 & 2 \\
61 & 3 & 0 & 5 & 0 & 1 & 11 & 2 & 1 \\
62 & 2 & 0 & 5 & 2 & 6 & 18 & 3 & 1 \\
63 & 1 & 0 & 1 & 0 & 3 & 4 & 0 & 4 \\
64 & 1 & 0 & 0 & 0 & 0 & 3 & 0 & 1 \\
65 & 13 & 0 & 12 & 3 & 9 & 38 & 11 & 15 \\
66 & 7 & 1 & 3 & 1 & 7 & 19 & 9 & 4 \\
67 & 1 & 0 & 0 & 0 & 7 & 11 & 0 & 1 \\
74 & 6 & 3 & 4 & 0 & 2 & 14 & 6 & 6 \\
75 & 3 & 1 & 6 & 0 & 2 & 8 & 2 & 4 \\
76 & 22 & 3 & 21 & 5 & 17 & 51 & 11 & 9 \\
77 & 2 & 1 & 2 & 0 & 1 & 6 & 1 & 1 \\
78 & 1 & 0 & 0 & 0 & 0 & 2 & 0 & 0 \\
84 & 6 & 1 & 8 & 0 & 5 & 7 & 0 & 0 \\
85 & 106 & 27 & 117 & 22 & 133 & 353 & 73 & 63 \\
86 & 27 & 3 & 11 & 3 & 4 & 22 & 2 & 1 \\
87 & 0 & 0 & 1 & 1 & 2 & 32 & 9 & 14 \\
88 & 0 & 0 & 0 & 0 & 2 & 4 & 1 & 0 \\
89 & 2 & 1 & 0 & 0 & 0 & 3 & 0 & 1 \\
90 & 10 & 3 & 17 & 1 & 15 & 36 & 5 & 10 \\
91 & 22 & 1 & 25 & 3 & 21 & 30 & 3 & 0 \\
92 & 0 & 0 & 0 & 0 & 0 & 2 & 0 & 0 \\
\hline TOTAL & 301 & 58 & 331 & 63 & 325 & 929 & 164 & 173 \\
\hline
\end{tabular}




\section{BIBLIOGRAFIA}

ALtUNA, J., 1972: “Fauna de mamíferos de los yacimientos prehistóricos de Guipúzcoa. Con catálogo de los Mamíferos Cuaternarios del Cantábrico y del Pirineo Occidental», Munibe, núm. 24, San Sebastián. Aranzadi Zientzi Elkartea - Sociedad de Ciencias Aranzadi, 469 págs. Altuna, J.; Baldeón, A.; Mariezkurrena, K., 1985: "Cazadores madgalenienses en Erralla (Cestona, País Vasco)», Munibe, núm. 37, San Sebastián. Aranzadi Zientzi Elkartea - Sociedad de Ciencias Aranzadi, 206 págs.

Altuna, J.; Merino, J. M., 1984: El yacimiento prehistórico de la cueva de Ekain (Deba, Guipúzcoa). San Sebastián. Eusko Ikaskuntza-Sociedad de Estudios Vascos, 351 págs.

Arambourou, R., 1978: Le gisement préhistorique de Duruthy a SordeL'Abbaye (Landes), Mémoires de la Société Préhistorique Française, núm. 13,158 págs.

Arribas, J. L.; BerganzA, E., 1988: “El yacimiento de la cueva de Laminak II (Berriatúa, Bizkaia)", Kobie, núm. XVII. Biskaiko Foru Aldundia - Diputación Foral de Vizcaya. Bilbao, págs. 7-24.

Barandiaran, I., 1967: Paleomesolítico del Pirineo Occidental. Bases para una sistematización tipológica del instrumental óseo paleolítico, Monografias Arqueológicas III. Zaragoza. Universidad de Zaragoza.

- 1979: "Excavaciones del covacho de Berroberría (Urdax). Campaña de 1977", Trabajos de Arqueologia Navarra, núm. 1, Pamplona, págs. 27-72.

Barandiará, J. M.; Sonneville-Bordes, D., 1964: “Magdalénien final et Azilien d'Urtiaga (Guipúzcoa): Étude statistique", Miscelánea en homenaje al Abate Breuil I. Barcelona, págs. 171-193. 
Bernaldo de Quirós, F., 1980: Notas sobre la economia del Paleolítico Superior, Monografías del Centro de Investigación y Museo de Altamira, núm. 1. Santander, Ministerio de Cultura, 44 págs.

Bernaldo de Quirós, F.; Gutiéraez, C.; Laguera, M. A.; Pelayo, M.; Pumarejo, P.; Uzquiano, P. (en prensa). “Nouvelles donnes sur la transition Magdalénien Supérieur - Azilien: la Cueva de La Pila (Cantabria, Espagne)", Le peuplement magdalénien. Paléogeographie physique et humaine. Chancelade 1988.

BreuIL, H., 1905: "Les subdivisions du Paléolithique Supérieur et leur signification", XIV eme Congrés International d'Anthropologie et d'Archaélogie Préhistorique, págs. 63-74.

Bordes, F., 1961: Typologie du Paléolithique Ancien et Moyen. Burdeos, Ed. Delmas, 85 págs.

Cabrera, V., 1984: El yacimiento de la cueva de "El Castillo" (Puente Viesgo, Santander), Biblioteca Praehistorica Hispanica XXII. Madrid, 485 págs.

CELERIER, S., 1979: «Inventaire morphologique de pointes aziliennes en Périgord. Un projet de rationalisation", La fin des Temps Glaciares en Europe. París, C.N.R.S., págs. 461-466.

Corchon, M. S., 1981: "Cueva de Las Caldas. San Juan de Priorio (Oviedo)", Excavaciones Arqueológicas en España, núm 53, Madrid, 268 págs.

Crowe, W., 1985: «Técnicas de recuperación integral de los datos obtenidos en los sedimentos de yacimientos prehistóricos". En Barandiarán, I.; Freeman, L. G.; González Echegaray, J.; Klein, R. G., Excavaciones en la Cueva del Juyo, Monografías del Centro de Investigación y Museo de Altamira, núm. 14. Santander, Ministerio de Cultura, págs. 63-74.

DJINJIAN, F., 1984: "Typologie et culture", "La significatio culturelle des industries lithiques", editado por Otte, M. Estudia Praehistorica Be/gica, núm. 4. BAR Internacional Series núm. 239, págs. 338-372.

Fernandez-TResguerres, J. A., 1980: El Aziliense en las provincias de Asturias y Santander, Monografias del Centro de Investigación y Museo de Altamira, núm. 2. Santander, Ministerio de Cultura, 214 págs.

Fernández Eraso, J., 1985: Las Culturas del Tardiglaciar en Vizcaya. Vitoria. Universidad del País Vasco, Vitoria, 619 págs.

FREEMAN, L. G., 1973: "The significance of mammalian faunes from Paleolithic occupations in Cantabrian Spain", American Antiquity, número 38 , núm. 1, págs. 3-44.

Garcia GuineA y otros, 1985: "Las cuevas azilienses de El Piélago (Mirones, Cantabria) y sus excavaciones de 1967-1969", Sautuola IV, págs. 13-153. 
González Echegaray, J., 1966: "Sobre la cronología de la glaciación wurmiense en la costa cantábrica», Ampurias, XXVIII, Barcelona, págs. 1-9.

- 1972-73: «Consideraciones climáticas y ecológicas sobre el Magdaleniense III en el norte de España», Zephyrus, XXIII-XXIV, Salamanca, págs. 167-187.

González Echegaray, J.; Barandiarán, I., 1981: El Paleolítico Superior de la Cueva de Rascaño, Monografías del Centro de Investigación y Museo de Altamira, núm. 3. Santander, Ministerio de Cultura.

Gonzalez Echegaray, J., y otros, 1980: El yacimiento de la cueva de El Pendo. Excavaciones 1953-1957, Biblioteca Prehistorica Hispanica, núm. 17. Madrid.

Gonzalez Echegaray, J.; Freeman, L. G. 1971: Cueva Morín. Excavaciones 1966-68, Monografia, VI, del Patronato de las Cuevas Prehistóricas de la Provincia de Santander. Santander.

Gonzále.z Echegaray, J.; Freeman, L. G., 1973: Cueva Morín. Excavaciones 1969, Monografía, X, del Patronato de las Cuevas Prehistóricas de la provincia de Santander. Santander.

González Echegaray, J.; García Guinea, M. A.; Begines Ramirez, A., 1971: Cueva de El Otero, Excavaciones Arqueológicas en España, núm. 53. Madrid.

GonzAlez SaInZ, C., 1988: El Magdaleniense Superior-Final de la región cantábrica. Santander. Ediciones Tantín y Servicio de Publicaciones de la Universidad de Cantabria, Santander, 318 págs.

González Sainz, C.; González Morales, M., 1986: La Prehistoria en Cantabria. Santander. Ed. Tantín.

Gutiérrez, C.; Heras, C.; Bernaldo de Quirós, F., (en prensa): «Arte mueble figurativo de la cueva de La Pila (Cuchía, Cantabria)", Ars Praehistorica, V, Barcelona.

HODDER, I., 1982: Symbols in action. Cambridge.

Hoyos Gómez, M.; Laville, H., 1982: "Nuevas aportaciones sobre la estratigrafía de los depósitos del Paleolítico Superior de la Cueva de El Pendo (Santander): sus implicaciones», Zephyrus, t. 34-35, Salamanca, págs. 285-293.

Hoyos Gómez, M.; Martinez Navarrete, M. I.; Chapa, T.; Castaños, P.; SÁnchez, F. B., 1980: La Cueva de La Paloma, Soto de la Reguera (Asturias), Excavaciones Arqueológicas en España, núm. 116, Madrid, 227 págs.

ibañez Estévez, J. J.; González Urquijo, J. E., 1988: "Tecnología de talla en el yacimiento de Laminak II (Berriatúa, Bizkaia)", Kobie, núm. XVII. Biskaiko Foru Aldundia - Diputación Foral de Vizcaya, Bilbao, págs. 25-46. 
JORDÁ, J., 1958: Avance al estudio de la cueva de La Lloseta (Ardines, Ribadesella, Asturias), Memoria, núm. 3. Oviedo. (Servicio de Investigaciones Arqueológicas).

LAPLACE, S., 1972: La typologie analithique et structurale. Burdeos.

Lerol-Gourhan, A., 1971: Préhistoire de l'art occidental. París, Ed. Mazenod.

- 1983: Fouilles de Pincevent. Essai d'analyse ethnographique d'un habitat magdalénien (la section 36), VIII eme. supplément a Gallia Préhistoire. París, C.N.R.S., 345 págs.

Lerol-Gourhan, Arl., 1971: "Análisis polínico de Cueva Morín", en Gonzalez Echegaray, J.; Freeman, L. G., Cueva Morín. Excavaciones 1969, Monografía, VI, del Patronato de las Cuevas Prehistóricas de la Provincia de Santander. Santander, págs. 359-368.

- 1980: "Análisis polínico de El Pendo", en Gonzalez Echegaray, J., y otros: El yacimiento de la Cueva de El Pendo. Excavaciones 19531957. Biblioteca Prehistórica Hispánica, núm. 17. Madrid, págs. 263266.

Merino, J. M., 1980: Tipología lítica, Suplemento núm. 4 a Munibe. Aranzadi Zientzi Elkartea - Sociedad de Ciencias Aranzadi, San Sebastián, 186 págs.

Moure Romanillo, J. A., 1975: Excavaciones en la cueva de Tito Bustillo (Ribadesella, Asturias). Campañas de 1972 y 1974. Oviedo, Instituto de Estudios Asturianos.

Moure Romanillo, J. A.; Cano Herrera, M., 1975: Excavaciones de la cueva de Tito Bustillo (Asturias). Trabajos de 1975. Oviedo, Instituto de Estudios Asturianos.

Obermaier, H., 1925: El Hombre Fósil, Comisión de Investigaciones Paleontológicas y Prehistóricas, núm. 9. Madrid, 457 págs.

OLIVA, M., 1984: «La signification culturelle des industries paléolithiques: l'approche psico-sociale", La signification culturelle des industries lithiques, editado por Otte, M. Studia Praehistorica. Belgica, núm. 4. BAR International Series núm. 239, págs. 92-114.

- 1988: Une habitation magdalénienne d'Étoilles. L'Unité P15, Mémoires de la Société Préhistorique Française, t. núm. 20. París, 175 págs.

PIGEOT, N., 1987: Magdaléniens d'Étiolles. Économie de débitage et organisation sociale, XXVème supplément à Gallia Préhistoire. París, C.N.R.S., 157 págs.

Sonneville-Bordes, D.; Perrot, J., 1954-56: "Lexique tipologique du Paléolithique Supérieur, Bulletin de la Société Préhistorique Française, t. 51,52 y 53 . Paris. 
Strauss, L. G., 1983: El solutrense vasco-cantábrico. Una nueva perspectiva, Monografías del Centro de Investigación y Museo de Altamira, núm. 3. Santander, Ministerio de Cultura, 173 págs.

Strauss, L. G.; Clark, G. A., 1986: "La Riera Cave», Antropological Research Papers, núm. 36. Phoenix, Arizona State University, 499 págs.

UtRILLA, P., 1981: El Magdaleniense Inferior y Medio en la costa cantábrica, Monografias del Centro de Investigación y Museo de Altamira, núm. 3. Santander, Ministerio de Cultura, 335 págs.

UtRILlA, P.; LOPEZ, P.; MAZO, C., 1986: «Interpretación microespacial de una ocupación magdaleniense a través de análisis polínicos y de huellas de uso", Arqueologia espacial. Coloquio sobre el microespacio, Teruel. Colegio Universitario de Teruel, T. 8, págs. 41-60.

VICENT, J. M., 1981: «Un concepto de metodología: hacia una diferenciación epistemológica diferencial en Prehistoria y Arqueologia", Actas de las Segundas Jornadas de Cáceres. Metodologia y Didáctica de la Historia (en prensa). 